Article

\title{
Expandable Houses: An Explorative Life Cycle Cost Analysis
}

\author{
Charlotte Cambier ${ }^{1, *}\left(\mathbb{D}\right.$, Waldo Galle ${ }^{1,2} \mathbb{D}$ and Niels De Temmerman ${ }^{1}[$ \\ 1 Department of Architectural Engineering, Vrije Universiteit Brussel, 1050 Brussels, Belgium; \\ Waldo.Galle@vub.be (W.G.); Niels.De.Temmerman@vub.be (N.D.T.) \\ 2 VITO Transition Platform, Flemish Institute for Technical Research, Boeretang 200, 2400 Mol, Belgium \\ * Correspondence: Charlotte.Cambier@vub.be; Tel.: +32-(0)2-629-1872
}

check for updates

Citation: Cambier, C.; Galle, W.; De Temmerman, N. Expandable Houses: An Explorative Life Cycle Cost Analysis. Sustainability 2021, 13, 6974 https: / doi.org/10.3390/su13126974

Academic Editors: Vincent Gruis and Tillmann Klein

Received: 16 April 2021

Accepted: 15 June 2021

Published: 21 June 2021

Publisher's Note: MDPI stays neutral with regard to jurisdictional claims in published maps and institutional affiliations.

Copyright: (c) 2021 by the authors. Licensee MDPI, Basel, Switzerland. This article is an open access article distributed under the terms and conditions of the Creative Commons Attribution (CC BY) license (https:// creativecommons.org/licenses/by/ $4.0 /)$.

\begin{abstract}
In addition to the environmental burden of its construction and demolition activities, the Flemish housing market faces a structural affordability challenge. As one possible answer, this research explores the potential of so-called expandable houses, being built increasingly often. Through specific design choices that enable the disassembly and future reuse of individual components and so align with the idea of a circular economy, expandable houses promise to provide ever-changing homes with a smaller impact on the environment and at a lower cost for clients. In this paper, an expandable house suitable for various housing needs is conceived through a scenario-based research-by-design approach and compared to a reference house for Flanders. Subsequently, for both houses the life cycle costs are calculated and compared. The results of this exploration support the proposition that designing expandable houses can be a catalyst for sustainable, circular housing development and that households could benefit from its social, economic and ecological qualities. It requires, however, a dynamic perspective on evaluating their life-cycle impact.
\end{abstract}

Keywords: design for change; housing; life cycle costing; transformable architecture; adaptable buildings; sustainable architecture

\section{Introduction}

\subsection{Challenges in the Flemish Housing Market}

The housing market in the Belgian region Flanders faces various challenges. First, in the context of the demographic trends, where the urban population is growing and accelerating [1,2], the number of people seeking a home and the demand for housing keeps increasing. Moreover, the average household size is shrinking [3] because of family dilution and ageing, and therefore the demand for global construction is expected to increase by $70 \%$ over the next few years [4]. This observation rings alarm bells in terms of environmental impact. Large quantities of raw materials will be needed for all those construction and renovation projects and the construction and use of buildings are material and energyintensive. In Flanders, the construction sector is the largest consumer of raw materials and accounts for over $35 \%$ of the total waste generation [2,5-7].

Second, also in terms of affordability concerns are rising. Since the mid-90s onwards housing prices have been increasing and the demand for affordable housing is high [8]. Moreover, compared to other European regions, Flanders has many inhabitants in relation to its area, which has an effect on land prices $[9,10]$. This and the earlier mentioned factors are expected to increase housing prices even more. Consequently, affordable housing is now one of the priorities in Belgian housing sector $[8,11]$. However, when a new (affordable) housing project is initiated, often an initial cost reduction for the client is the only objective. Other critical determinants, such as the quality of living or the divergent lifestyles of the targeted households, are absent or superficially tackled [12]. As a result, households must choose between (initial) price or level of comfort. The situation is even more dire when one considers that buying a house is often one of the largest investments in peoples' lives and that they desire qualitative homes in return. 
Third, the way households are organized has been changing increasingly faster and less traditional family compositions have emerged. For example, the growing divorce rate generates single-parent households and remarrying creates new composed families [3]. When such or other changes in lifestyle occur, residents often give up some quality of living or, if financially capable, adapt the house to their new needs. Expanding the kitchen or adding new walls are examples of these adaptations. If the needs or the financial status change largely, the household can consider relocation to avoid costly and complex refurbishments. This results from contemporary housing being built in an inflexible way and thereby prone to obsolescence [13].

\subsection{Design for Change}

Therefore, reassessing how houses are conceived is necessary, and challenging the traditional thinking regarding housing is urgent [14]. In this study, the influence of the alternative design approach Design for Change (DfC) will be analyzed. DfC is a design and construction strategy based on the principle that the requirements and aspirations of society and users on our built environment will always change [15]. These changing requirements are, among others, changing standards, family composition, changing patterns of life and an evolving work environment [16]. The aim is to make a building easily adaptable during its lifetime and, in this study, to design dwellings to become life-cycle houses that truly support changes. This design strategy aligns with the idea of circular economy. According to Kirchherr et al. [17], who identified 114 different CE definitions, a circular economy can be defined as "an economic system that is based on business models which replace the 'endof-life' concept with reducing, alternatively reusing, recycling and recovering materials [...] with the aim to accomplish sustainable development [...]." In this regard, previous studies have shown that applying a design that anticipates the whole life cycle of a building has the potential to decrease its environmental impact [16] because integrating adaptability promotes less material consumption and less demolition waste [18], as buildings are reconfigured instead of demolished and rebuilt. Moreover, a house that is initially designed to adapt to changing lifestyles is expected to have lower adaptation costs [19].

\subsection{Expandable Houses}

One particular implementation of the DfC strategy are the so-called 'expandable houses' or 'incremental houses'. This housing form is being built increasingly often, both in developing [20,21] and developed countries [22]. Generally, an expandable house has the ability to add expansions whenever desired and feasible by its residents. Therefore, over their lifetime, expandable houses promise to provide ever-changing homes at a lower cost for clients and with a smaller impact on the environment. The objective of this study is to explore the potential of such expandable houses in terms of life cycle costs while reflecting about the suitable methods to evaluate these hypotheses.

\section{Methods}

A variety of methods are used to explore the potential of expandable houses in terms of life cycle costs. These various methods are outlined in the dark grey areas of Figure 1. 


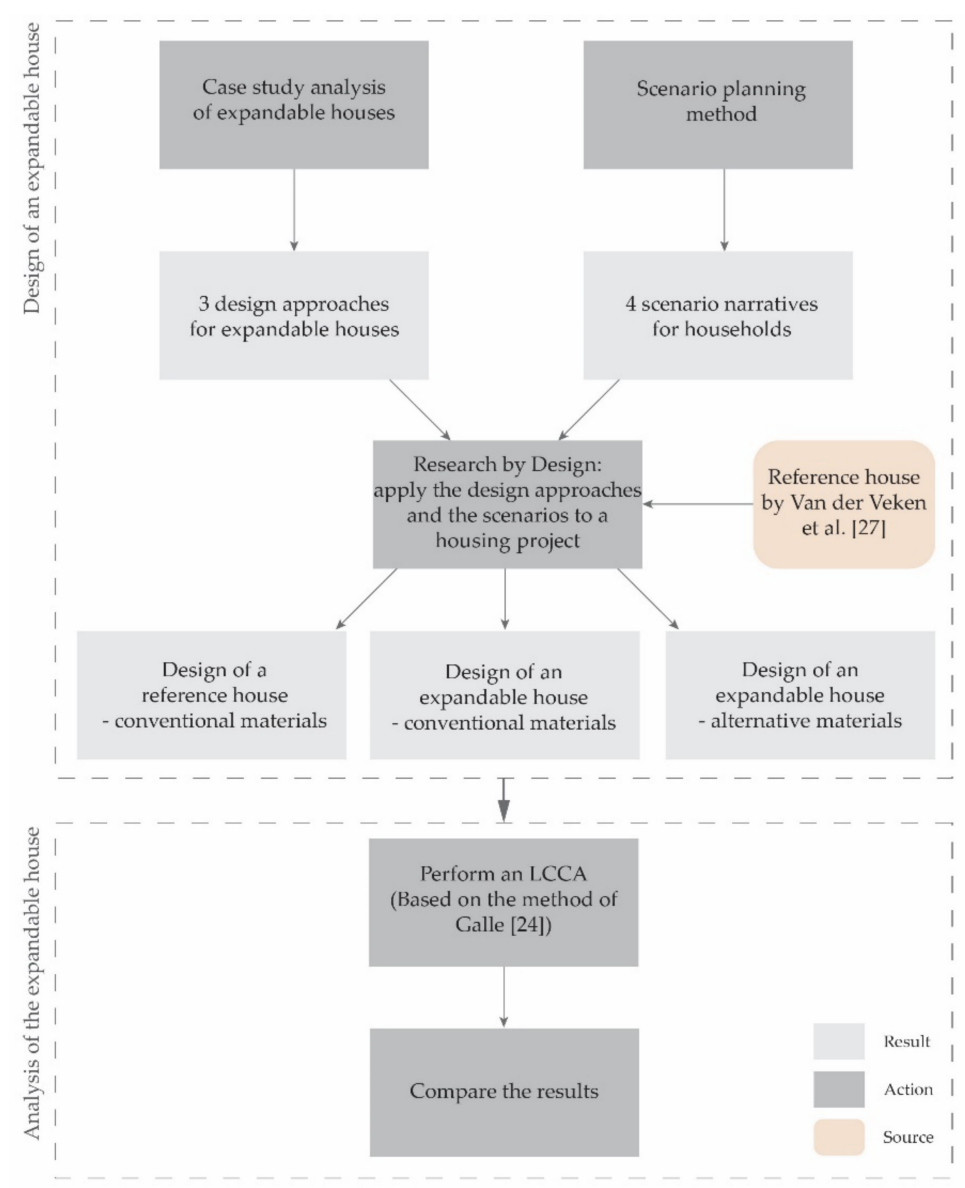

Figure 1. Scheme of the used methods.

Second, expandable houses are designed to adapt to different life styles. In this research, the scenario planning method was used to determine these life styles. Scenario planning aids to create multiple futures based on uncertainties and drivers and therefore it has the ability to help imagining and anticipating plausible future households in Flanders according to the demographical statistics and the values of society [23,24].

Once the design approaches and the scenario narratives were defined, they were combined by applying them to a building project. This application of the design approaches and scenario narratives was completed through a Research by Design method. Proceeding from the authors' design expertise, also this research allows to, as stated by Hauberg [25], "produce new knowledge about the world through the act of designing", in particular modelling various service lives and future refurbishments of the expandable house. Further, it was necessary to define a reference house to compare with in order to make valuable conclusions. Therefore, the fictional row house representative for the low-end segment of Flemish housing market $[9,26]$ as discussed by Van der Veken et al. [27] was adopted in this study.

The design of the expandable house, i.e., in its initial state and in its various possible expanded states, originated from two givens. The first given is the functionality of the reference house. This is significant, since the expandable house must be able to fulfill that function too, for it to be comparable. The second given is the minimum floor areas set by the Flemish Society for Social Housing (VMSW) [26]. These floor areas are defined to balance cost efficient housing and comfortable dwelling.

To narrow down this exploration, the houses' designs were limited to one of the identified design approaches for expandable houses and three out of four scenario narratives (see the green area in Figure 2). This allowed us to compare two different house designs, being adapted over time according to three plausible scenario narratives. 


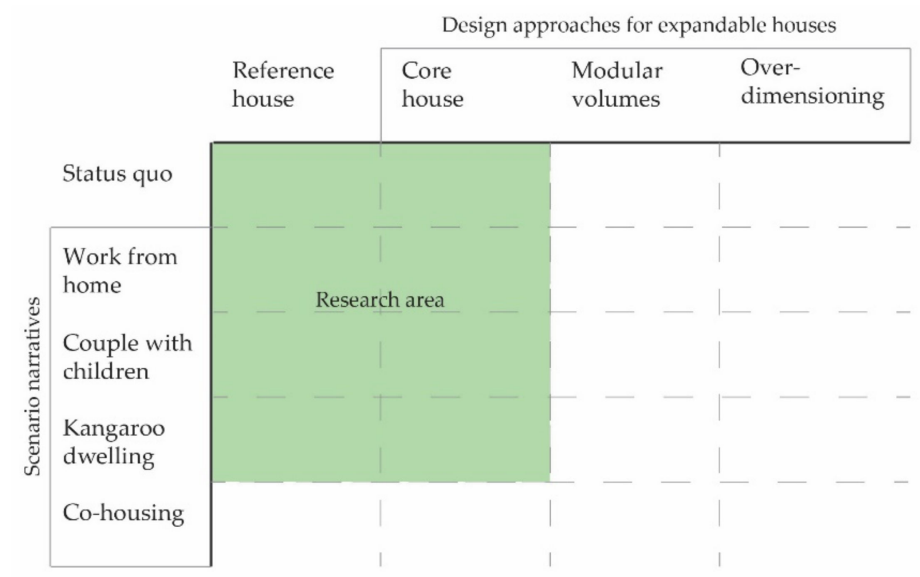

Figure 2. The research area (green) covered in this study.

Prior to calculating the financial costs, the building elements and their materials must be defined. After all, the costs are dependent on the quantities (volume and weight) of the materials, their expected technical service life, and the construction and operational costs [24]. This was completed for three design alternatives. For the first design alternative, i.e., the conventional reference house from the study of Van der Veken et al. [27], also their proposal for building elements and materials is adopted. In contrast, when designing for change, it is advised to use reversible connections and manageable elements to ease the transformation process and to avoid demolition and construction waste [28]. Therefore, a second design alternative, i.e., the expandable house with conventional building elements, and a third design alternative, i.e., the expandable house with DfC assemblies, are designed and detailed. The detailing of the demountable building elements is elaborated with reference to the research of Vandenbroucke et al. [16].

From these element and material definitions, the financial costs and benefits of the reference house and the two expandable houses are analyzed. The financial costs are calculated through the scenario-based Life Cycle Cost analysis (LCC) method developed by Galle [24]. LCC is a long-term financial evaluation method. It does not only consider the investment costs. It estimates all relevant costs and savings throughout the service life of a building including for example maintenance, use and end-of-life costs [29]. Since possible savings of expandable houses are situated further in time, LCC is relevant to understand their eventual added value in financial terms. Correspondingly, LCC can be considered as one proxy for the affordability of housing, especially if user-owned, which is the most common in Flanders (in 2018, 72\% of the households owned the house in which they live) and which continues to be supported by the regional government [30,31]. Finally, to come to conclusions, the life cycle cost of the reference house is compared to that of the two versions of the expandable house.

\section{Design of an Expandable House}

\subsection{Design Approaches for Expandable Houses}

\subsubsection{Case Studies of Expandable Houses}

A case study analysis was used to identify design approaches for expandable houses. Following an open query in architectural literature, nine projects wherein the house can expand and/or shrink intentionally, were analyzed (Table 1). Although it is not the intention to be complete, a diversity of cases was aspired. Their possible expansions occurred in various forms and range from the simple addition of a self-standing module to the extension with a large and complex volume up to the size of an adjacent dwelling. 
Table 1. Selected case studies of expandable houses.

\begin{tabular}{|c|c|c|c|c|}
\hline Nr. & Case Study & Place & Completion Date & Characteristics/Concept \\
\hline 1 & $\begin{array}{c}\text { Quinta Monroy } \\
\text { by ELEMENTAL } \\
{[33,34]}\end{array}$ & Iquique, Chile & 2003 & $\begin{array}{c}\text { Extensions, people } \\
\text { architecture, cost-efficient }\end{array}$ \\
\hline 2 & $\begin{array}{c}\text { Skilpod } \\
\text { by UAU Collectiv } \\
{[35,36]}\end{array}$ & Belgium & 2016-today & Modular volumes, replaceable \\
\hline 3 & $\begin{array}{c}\text { Nakagin capsule } \\
\text { tower } \\
\text { by Kisho Kurokawa } \\
{[37,38]}\end{array}$ & Tokyo, Japan & 1972 & $\begin{array}{c}\text { Modular volumes, } \\
\text { prefabrication, quick assembly }\end{array}$ \\
\hline 4 & $\begin{array}{l}\text { Sharifi-Ha House } \\
\text { by Next Office [39] }\end{array}$ & Tehran, Iran & 2014 & $\begin{array}{l}\text { Manipulation of volumes, } \\
\text { box-in-box principle }\end{array}$ \\
\hline 5 & $\begin{array}{l}\text { Sliding House } \\
\text { by dRMM Architects } \\
\text { [40] }\end{array}$ & Suffolk, UK & 2009 & Manipulation of volumes \\
\hline 6 & $\begin{array}{c}\text { Aquitanis } \\
\text { by Tetrarc Architects } \\
{[41]}\end{array}$ & Bordeaux, France & 2016 & $\begin{array}{l}\text { Modularity, core house, } \\
\text { prefabrication }\end{array}$ \\
\hline 7 & $\begin{array}{c}\text { ME:LU } \\
\text { by AB Design studio } \\
\text { [42] }\end{array}$ & Los Angeles, USA & - & $\begin{array}{l}\text { Modularity, reuse of } \\
\text { containers }\end{array}$ \\
\hline 8 & $\begin{array}{c}\text { IbbN } \\
\text { by Koos Van Lith [32] }\end{array}$ & $\begin{array}{l}\text { Nijmegen, The } \\
\text { Netherlands }\end{array}$ & - & $\begin{array}{l}\text { Cost-efficient, kit-of-parts, } \\
\text { rapid construction }\end{array}$ \\
\hline 9 & $\begin{array}{l}\text { The Next Home } \\
\text { by Avi Friedman [43] }\end{array}$ & Montreal, Canada & - & $\begin{array}{c}\text { Cost-efficient, } \\
\text { over-dimensioning }\end{array}$ \\
\hline
\end{tabular}

From the analysis it appeared that most of these expandable house projects were designed and built for the most conventional household typology: the single-family household. Only a few cases also focused on less common household types, such as Skilpod which addresses multigenerational living or The Next Home that facilitates cohousing. However, one goal was common to all projects, i.e., to offer the opportunity to adapt the building to the needs and lifestyle of the inhabitants.

Multiple cases were explicit about their financial objectives and took an expandable design approach to become more affordable or cost-effective housing projects. For example, the designers of IbbN ( $I k$ bouw betaalbaar Nederland) focused on young-first time buyers [32]. Or, Quinta Monroy was created to revive a slum area; following the idea that the core house is conceived by professional designers and donated to the users by the municipality, but that the extensions are made entirely by the residents, whenever feasible for them $[33,34]$. These cases strengthened and partially confirmed the hypothesis that expandable houses can provide housing at a lower cost for clients.

\subsubsection{Design Approaches for Expandable Houses}

Through the analysis of the expandable housing projects, three archetypical design approaches for expandable houses were distilled: the core house, modular volumes and over-dimensioning (Figure 3).

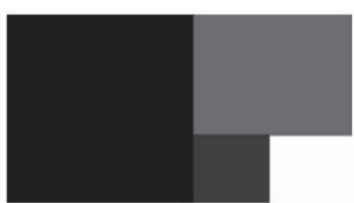

Design approach 1: Core house

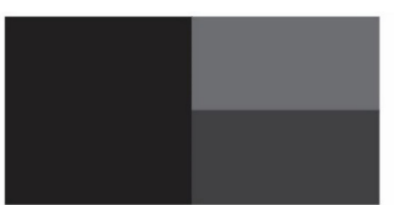

Design approach 2: Modular volumes

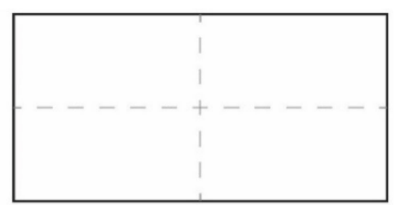

Design approach 3 : Over-dimensioning

Figure 3. Conceptual schemes of the design approaches for expandable houses.

The core house approach entails that the house should be able to scale down to a minimal core where all necessary functions, i.e., a minimal living space (including space for a bed), a kitchenette, a toilet, a bathroom and minimal storage space are included. Extensions are placed adjacent to the core or to an earlier extension. They can vary from a porch to a new level on top of the house. When designing the initial foundations and structure, future extensions (horizontally and vertically) are anticipated. 
The modular volumes design approach is similar to the core house approach, except for the use of modular volumes instead of custom-made extensions. As modules are repeated and thus often consist of standardized components, they can be chosen over custom-made structures to achieve cost effective and rapid construction [44,45]. Moreover, a modular system often uses a grid structure, that can be divided into several subsystems, which makes it easy to replace one of the subsystems [46]. Four of the analyzed cases included modular expansions, i.e., Skilpod, Nakagin Capsule Tower, ME:LU and Aquitanis.

The third approach, over-dimensioning, consists of a static frame structure of which the internal volume can be subdivided and rearranged. The difference with the previous design strategies is that the outer shell as such does not expand and the built floor area remains the same. Therefore, the outer shell should be large enough from the initial design stage. An open plan is indispensable for this design approach. Internal load-bearing walls should be avoided and the structural elements should be positioned in the outer shell as much as possible. Partitioning can be designed in a way that it accommodates maximal transformation possibilities with minimal hindrance and cost. Easily removable, adaptable or reusable inner walls are preferred to facilitate transformation [47].

Together, these three design approaches formed the first foundation for the present research by design and might serve as archetypes for other projects too. The second grounding for this exploration was the development of relevant scenario narratives about Flemish households.

\subsection{Development of Household Scenarios}

A scenario planning method was used to anticipate and model future expansions of expandable houses. This is done by first developing narratives about how a household its needs might change. These narratives can then be projected onto the design alternatives, whereafter, through research by design, their future refurbishments and service life can be modelled. Finally, these models served as an input for the LCC and material analyses.

\subsubsection{Scenario Development}

Scenario development starts from identifying future trends. There are two kind of trends: (1) trends that will certainly take place in the future, e.g., demography and ageing population [48], and (2) uncertain trends. These uncertain trends are the base for developing scenarios as they are the drivers for divergent future changes. In the case of housing, the uncertain trends are influenced by a complex whole of individual preferences and socio-economic circumstances that thrives a housing ideal [19]. The drivers for change that are found relevant for Flemish households include: functional requirements of users, speed of change, extent of change, user behavior, the number of nuclei in a household and household type.

Accordingly, future scenarios are developed by selecting the most determining drivers for change. The two drivers selected for this exploration are requirements of the users and the number of nuclei. These two drivers are then put on axes, where 'requirements of the users' is put on the $y$-axis and 'number of nuclei' on the $x$-axis.

The plotted matrix subsequently generates four scenarios (Figure 4). Each scenario is an illustrative narrative wherein a household of one or two persons (which is a common starting point for housing clients [48]) evolves into divergent situations. They are: 'work from home' (one nucleus and working activities), 'couple with children' (one nucleus and only household activity), 'kangaroo dwelling' (multiple nuclei and caring activities) and 'co-housing' (multiple nuclei and only household activities). 


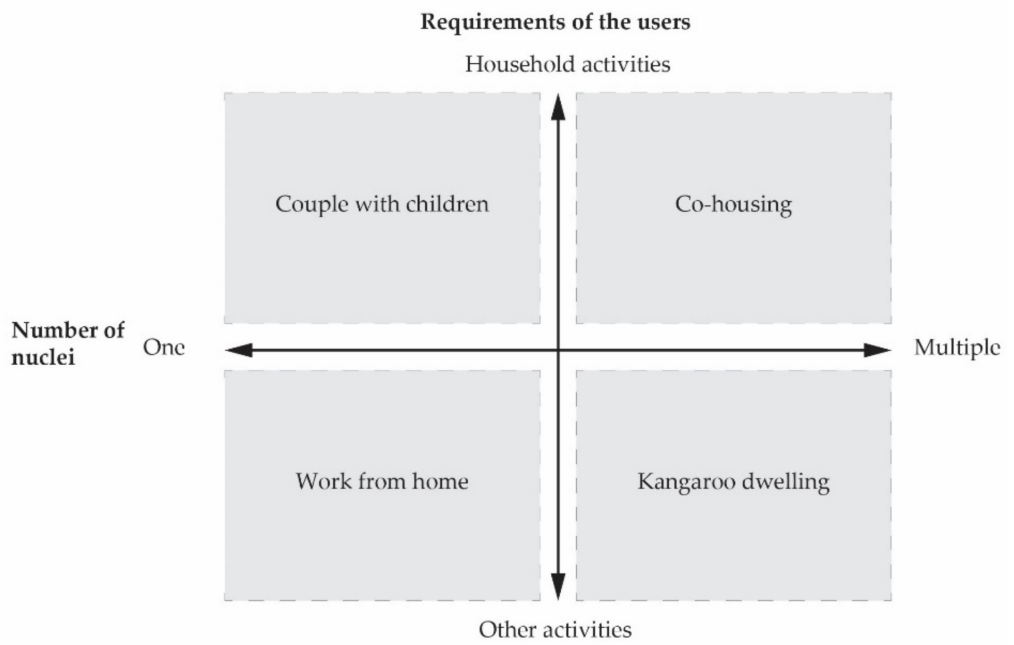

Figure 4. Key drivers for future change are plotted against each other as a basis for the development of four divergent scenario narratives. In this study, the selected drivers are the requirements of the users (vertical axis) and the number of nuclei in the household (horizontal axis).

Each of these four identified plausible future households can then be elaborated by putting them on a timeline. To do so, a period of analysis and the refurbishment frequency should be chosen [24]. The period of analysis is the time span that is considered and after which the house reaches its end-of-life, whereas the refurbishment frequency is the time span after which a change is made in the scenario narrative. In this research, a period of analysis of 60 years was chosen in accordance with the regionally approved life cycle assessment method MMG and other life cycle assessment studies in Flanders [49,50]. This means that the house is demolished or disassembled in year 60. To plot the transformations, a refurbishment frequency of 15 years (in the case of three transformations) or 30 years (in the case of one transformation) was chosen.

Scenario 1: Work from home.

The 'work from home' scenario does not imply changes to the household size compared to a one- or two-person household, but the activity changes from only a residential use to the addition of working activities (Figure 5). From a design view, the work at home scenario implies at least one extra, secluded room that can serve as an office. It can be related to trends such as increased digitalization, globalization, labor flexibility, as well as crises such as a pandemic and traffic congestions requiring many to change their working regime and location [51].

\begin{tabular}{ll} 
One or two persons & Work from home \\
\hline 0 & 30
\end{tabular}

Figure 5. Work from home scenario narrative.

Scenario narrative 2: Couple with children.

The second scenario narrative is the 'conventional' household development, wherein in the initial phase a single person lives alone or with a partner and subsequently the family grows to a nuclear family. After the children have grown up, they leave the house and the couple remains (Figure 6). Most parents (82\% in Flanders in 2014) have one or two children and only $4 \%$ have more than three children [52]. To evolve from 'one person' towards 'parents + children', additional rooms need to be created and more space needs to be made 
for living so that the dwelling can support this larger household. By choosing a life cycle of 60 years and variables of 15 years, the expandable house expands at 15 and 30 years due to the growing of the family, and shrinks at 45 years when the children are moving out.

\begin{tabular}{|c|c|c|c|c|}
\hline $\begin{array}{l}\text { One or two persons } \\
\text { in }\end{array}$ & $\begin{array}{l}\text { Parents + child } \\
\text { iss }\end{array}$ & $\begin{array}{l}\text { Parents + children } \\
\end{array}$ & $\begin{array}{l}\text { One or two persons } \\
\dot{\boldsymbol{p}}\end{array}$ & $\begin{array}{l}\text { Demolition or } \\
\text { disassembly }\end{array}$ \\
\hline 0 & 15 & 30 & 45 & 60 years \\
\hline $\begin{array}{l}\text { Min. one bedroom } \\
\text { Min. one bathroom } \\
\text { Living space } \\
\text { Storage space }\end{array}$ & Extra bedroom & $\begin{array}{l}\text { Extra bedroom(s) } \\
\text { Extra bathroom }\end{array}$ & $\begin{array}{l}\text { Less bedrooms } \\
\text { A bathroom less }\end{array}$ & \\
\hline
\end{tabular}

Figure 6. Couple with children scenario narrative.

Scenario narrative 3: Kangaroo dwelling.

The population is continuously ageing [48]. This compels individuals to seek housing solutions such as nursing homes. The Flemish policy on housing and care strives for more independent living at home. Meanwhile the search for affordable housing for elderly, as for all people, is difficult [53,54]. A possible solution is creating kangaroo dwellings, i.e., a multigenerational dwelling, wherein elderly live together with their children or other relatives and where cohabitation and care take place under one roof. This is an example of nuclear household transforming into an extended one. This type of housing and living is not new in Flanders, as we know it from historical family farm housing [55]. However, recently-built standard dwellings are not foreseen for such living conditions.

With the change of the household type, the requirements also change, affecting the preferred number of spaces, the size of the rooms, the level of privacy etc. Therefore, it is often necessary to provide an extra bedroom, bathroom and living and storage space. Moreover, it is desirable that all the rooms for the elderly person are wheelchair accessible and that a separate entrance door is provided (Figure 7).

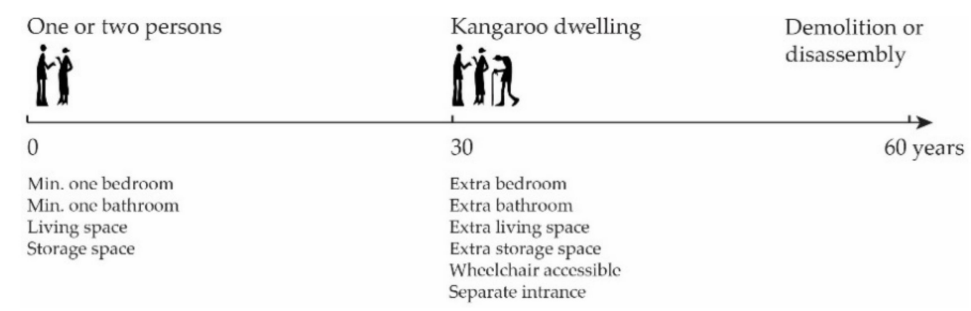

Figure 7. Kangaroo dwelling scenario narrative.

When the older person moves out, it is conceivable that the extra space could be reused for other purposes, such as housing for multiple families. However, in this research study it is assumed that the expansion will be removed again.

Scenario narrative 4: Co-housing.

Co-housing, broadly understood as a type of residential project wherein several housing units are merged and wherein private units are combined with common spaces and facilities [56,57]. It is an increasingly popular form of tenure [56,58]. Often, through its architecture, a co-housing project offers an opportunity for social interaction and common activities [56-59]. Therefore, in this scenario narrative, it should be possible to add some shared spaces and/or to transform some private spaces to commonly shared ones (Figure 8). 


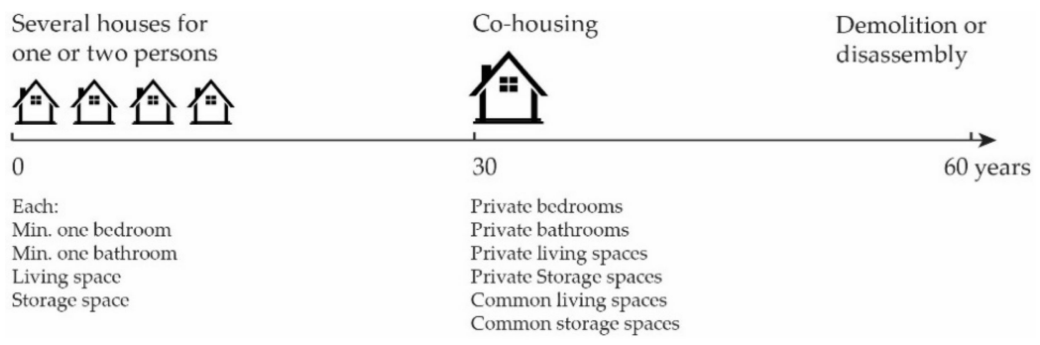

Figure 8. Co-housing scenario narrative.

\subsection{Elaboration of the Design Alternatives}

Previously, three archetypical design approaches for expandable houses were defined (Section 3.1.2.) and four different scenario narratives were developed (Section 3.2.1.). The next step is to apply these design approaches and narratives to a row house and detail the design alternatives, both conventional and expandable ones, with and without adapted material choices.

\subsubsection{Selection and Service Life Modelling of the Reference House}

To achieve a relevant comparison, it is required to first select a reference house. For this purpose, the row house defined by Van der Veken, Creylman and Lenaert [27] was adopted. The house consists of three floors and has four bedrooms and two bathrooms (Figure 9). The supporting structure consists of solid masonry walls, the floors consist of concrete slabs and the façade material is brickwork. The house has a pitched roof covered with tiles. Its net floor area is $175.58 \mathrm{~m}^{2}$.
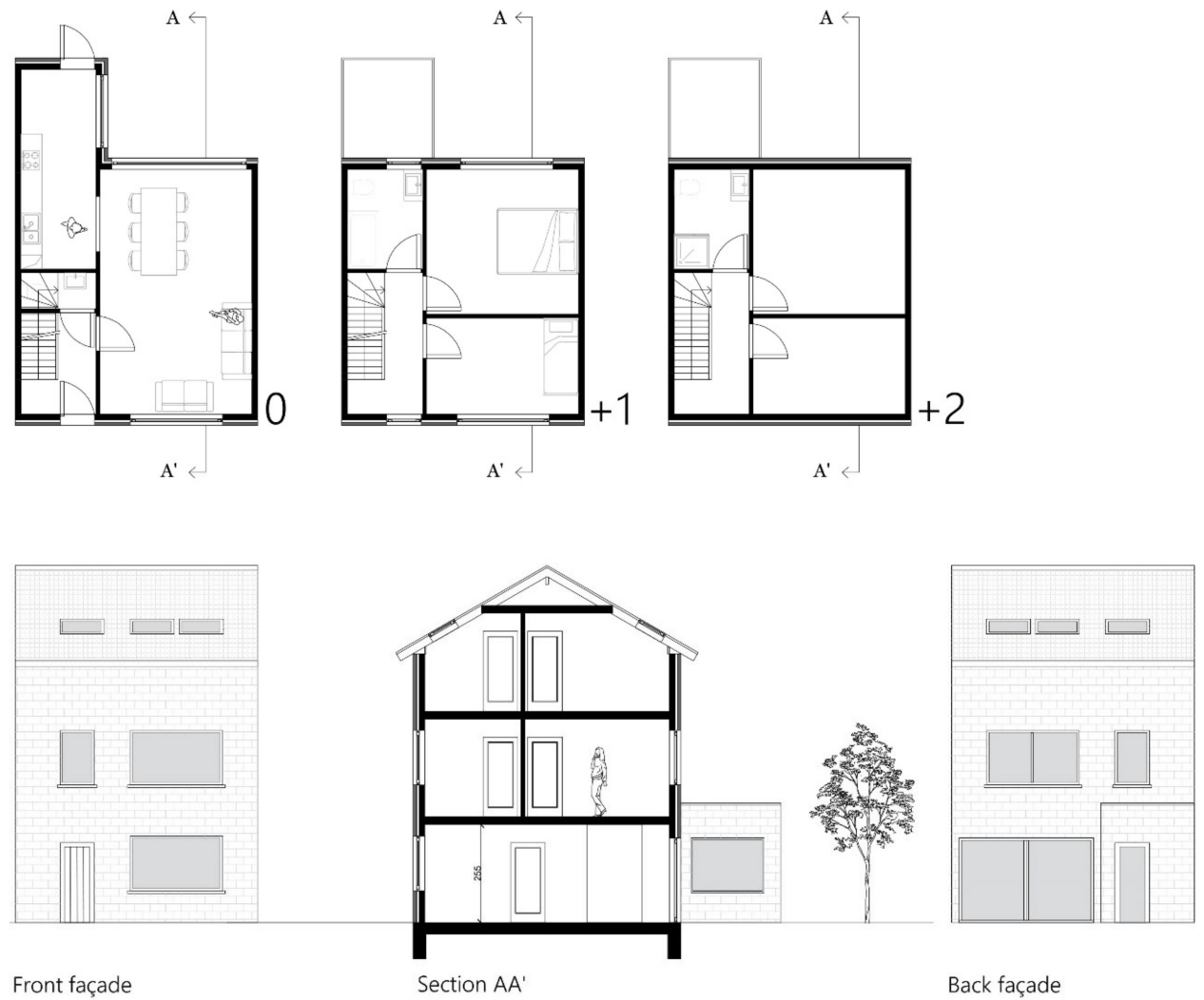

Figure 9. Floor plans, elevations and section $\mathrm{AA}^{\prime}$ of the reference row house. The design is based on the available information in [27].

The next step is to apply the scenario narratives to the reference house. Therefore, the house was redesigned and adapted for the changing needs in the scenarios 'work from 
home' and 'kangaroo dwelling'. The 'couple with children' scenario is not elaborated for the reference house, as this house is initially designed based on that household scenario. The designs of the future refurbishments of the reference row house for the 'work from home' and 'kangaroo dwelling' scenarios are available in Appendix A.

Next to the floor plans and the sections, also the building element's compositions and materialisation must be detailed to calculate the LCC. For the five most common building elements a representative composition is elaborated, based on the information provided by Van der Veken et al. [27]. The considered building elements are: a floor at ground level, a suspended floor, a roof, an exterior wall, and a partitioning wall. These building elements are further indicated as 'conventional elements'. Figure 10 shows the composition of the exterior wall. The details of the other elements are given in Appendix B.

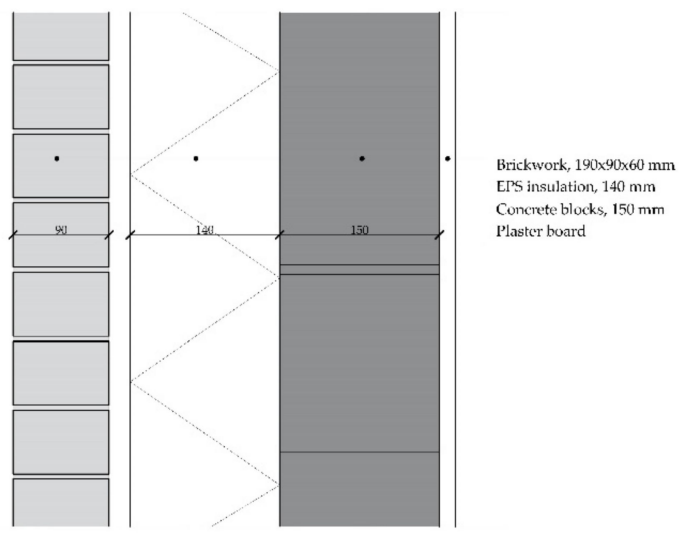

Figure 10. Representative composition and materialization of the exterior wall with conventional materials. The detailing is based on [27].

3.3.2. Design and Service Life Modelling of an Expandable House According to the 'Core House' Approach

Subsequently, the alternative expandable row house was designed. This exploration was limited to the 'core house' approach. It entails that the house is able to grow from, or to scale down to a minimal core with all necessary functions included, where nonmodular and unplanned extensions are added or removed to the core house when needed. These kinds of extensions are a typical Belgian renovation phenomenon [60,61]. Therefore, applying this design approach will produce a design that is more similar to a realistic situation. Moreover, this approach was, as we learned from the case study analysis, promising in terms of affordability.

Therefore, it takes into account the basic functionality of the reference house and fulfills the minimum floor areas determined by Flemish Society for Social Housing (VMSW) [26]. The design of the core house is shown in Figure 11. It has an entrance with a toilet, a living room and a kitchenette on the ground floor. To compensate the compact feeling, the backside is opened towards the garden. On the first floor, there is a bedroom, a bathroom and storage space. The initial floor area is $60 \mathrm{~m}^{2}$, sufficient to be occupied by one or two persons. 


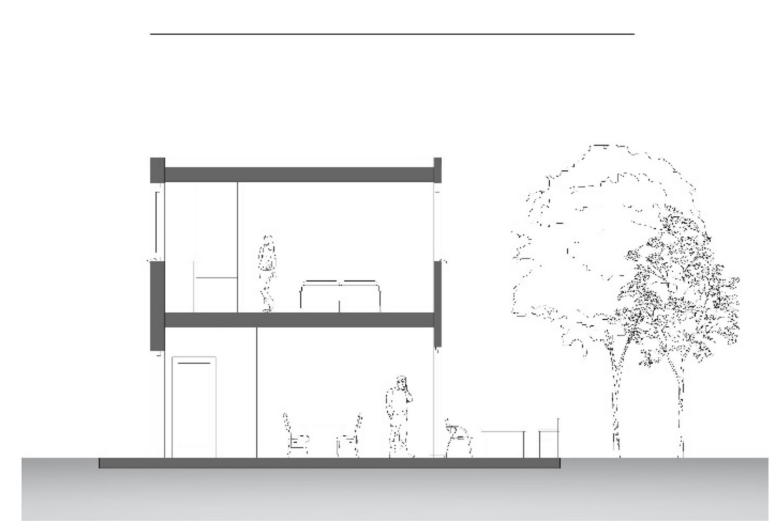

(a)
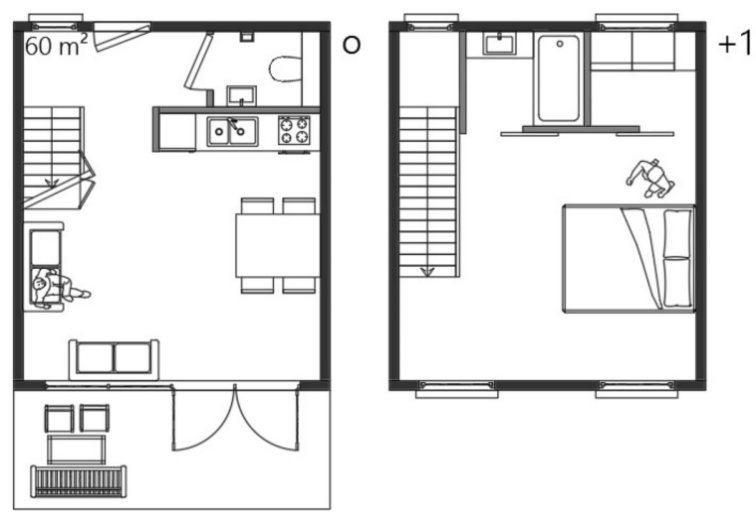

(b)

Figure 11. The design of the core house. (a) Section of the core house; (b) floor plans of the core house.

The designs for the future refurbishments of the expandable row house in the case of the 'work from home', the 'couple with children' and the 'kangaroo dwelling' scenarios were developed in a research-by-design fashion by the authors according to their knowledge of Flanders housing design practices and are made available in Appendix C.

When designing for change, it is encouraged to use reversible connections and manageable elements to ease the transformation process and avoid demolition and construction waste [28]. Therefore, next to the detailing of conventional building elements, alternative construction assemblies were also designed. This design of demountable building elements is elaborated with reference to the research of Vandenbroucke et al. [16]. Figure 12 shows the alternative composition of the exterior wall built for frequent adaptations. The detailing of the other building elements is presented in Appendix D.

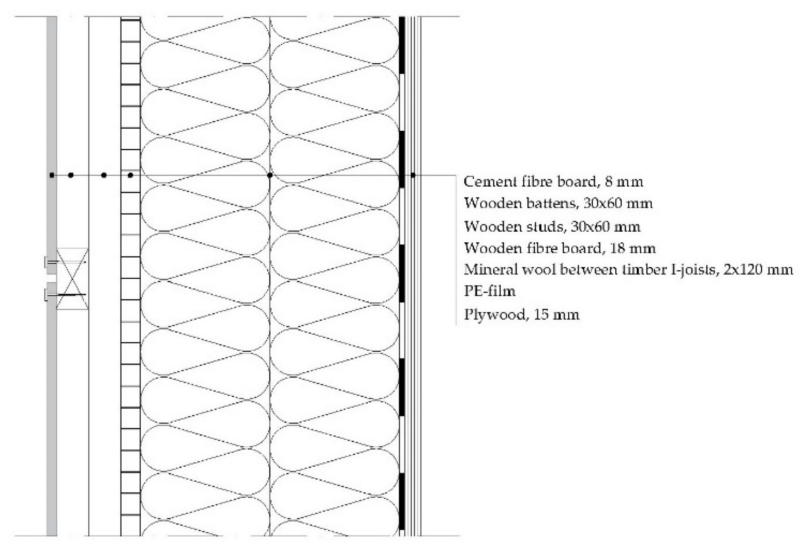

Figure 12. Composition and materialization of the exterior wall with alternative materials, suitable for disassembly and reuse. The detailing is based on [16].

\section{Life Cycle Cost Analysis and Comparison}

For the LCC calculations, the dimensions of the building elements and the estimated service life (esl) of its materials were collected as main input data. A building material has reached its estimated service life when it is no longer able to fulfil the requirements for which it was designed [62]. A replacement is then required, which includes its deconstruction or demolition and replacement. The service life of composed element depends on the estimated service life of its individual materials, their exact connection and composition which is reviewed for every element in this study [61]. The data for the estimated technical service lives were derived from BCIS (2006) [63] and collected in Table 2. 
Table 2. The estimated service life (esl) of the building components' materials, derived from [63].

\begin{tabular}{|c|c|c|c|c|c|}
\hline \multicolumn{3}{|c|}{ Conventional Building Elements } & \multicolumn{3}{|c|}{ Alternative Building Elements } \\
\hline Building Element & Material & Esl (Years) & Building Element & Material & Esl (Years) \\
\hline External wall & $\begin{array}{c}\text { Brickwork } \\
\text { EPS } \\
\text { Concrete blocks } \\
\text { Plaster board }\end{array}$ & $\begin{array}{l}75 \\
75 \\
75 \\
25\end{array}$ & External wall & $\begin{array}{l}\text { Cement fiber board } \\
\text { Wooden studs } \\
\text { Wooden fiber } \\
\text { board } \\
\text { Mineral wool } \\
\text { Timber frame } \\
\text { Plywood }\end{array}$ & $\begin{array}{l}25 \\
50 \\
30 \\
75 \\
74 \\
25\end{array}$ \\
\hline $\begin{array}{l}\text { External shared } \\
\text { wall }\end{array}$ & $\begin{array}{c}\text { EPS } \\
\text { Concrete } \\
\text { blocksPlaster boars }\end{array}$ & $\begin{array}{l}75 \\
75 \\
25\end{array}$ & $\begin{array}{c}\text { External shared } \\
\text { wall }\end{array}$ & $\begin{array}{l}\text { Mineral wool } \\
\text { Timber frame } \\
\text { Plywood }\end{array}$ & $\begin{array}{l}75 \\
75 \\
25\end{array}$ \\
\hline Window & $\begin{array}{l}\text { Aluminum } \\
\text { framing }\end{array}$ & 75 & Windows & $\begin{array}{l}\text { Aluminum } \\
\text { framing }\end{array}$ & 75 \\
\hline Internal wall & $\begin{array}{l}\text { Plaster board } \\
\text { Sand-lime bricks } \\
\text { Plaster board }\end{array}$ & $\begin{array}{l}25 \\
72 \\
25\end{array}$ & Internal walls & $\begin{array}{c}\text { Plywood } \\
\text { Wooden battens } \\
\text { Plywood }\end{array}$ & $\begin{array}{l}25 \\
72 \\
25\end{array}$ \\
\hline Floor & $\begin{array}{l}\text { Hardwood } \\
\text { Concrete } \\
\text { EPS } \\
\text { Concrete slab } \\
\text { Plaster board }\end{array}$ & $\begin{array}{l}25 \\
75 \\
75 \\
75 \\
25\end{array}$ & Floor & $\begin{array}{c}\text { Hardwood } \\
\text { Plywood } \\
\text { Wooden battens } \\
\text { Mineral wool } \\
\text { Plywood }\end{array}$ & $\begin{array}{l}25 \\
25 \\
75 \\
75 \\
25\end{array}$ \\
\hline Ground floor & $\begin{array}{l}\text { Laminate } \\
\text { Concrete } \\
\text { EPS } \\
\text { Concrete slab }\end{array}$ & $\begin{array}{l}30 \\
75 \\
75 \\
75\end{array}$ & Ground Floor & $\begin{array}{l}\text { Timber flooring } \\
\text { Wooden fiber } \\
\text { board } \\
\text { Mineral wool } \\
\text { Joists } \\
\text { Bearer }\end{array}$ & $\begin{array}{l}30 \\
30 \\
75 \\
70 \\
70\end{array}$ \\
\hline Roof & $\begin{array}{c}\text { Roof tiles } \\
\text { Rafters } \\
\text { EPS } \\
\text { Purlins } \\
\text { Plaster board }\end{array}$ & $\begin{array}{l}75 \\
50 \\
75 \\
50 \\
25\end{array}$ & Roof & $\begin{array}{c}\text { Gravel } \\
\text { PUR } \\
\text { Timber frame } \\
\text { Plywood }\end{array}$ & $\begin{array}{l}70 \\
75 \\
75 \\
25\end{array}$ \\
\hline
\end{tabular}

Building further on the LCC modelling method of Galle [24,64], the financial data that were used originates from ASPEN (2014) [65], an extensive database of average contractor prices in Belgium. They include labor, material and equipment costs, and were completed with data of Bouwunie (2014) [66] for specific waste flows and disassembly actions. What is not included are taxes, designer fees and the effects of possible mass production and prefabrication. These market-related uncertainties are also identified in other LCC models and must be evaluated in future research as it might have an impact on the final feasibility of the DfC approach, including the expandable housing concept [67]. These are however context specific (defined by local regulation in Flanders) and thus out of the scope of the present exploration.

The adopted model [24] is particularly interesting for the exploration of the longterm financial consequences of an expandable building design and its change-anticipating materialization since it makes the distinction between sorted and unsorted recovered components and between recyclable and unrecyclable materials. Moreover, with every expansion or shrinkage, or when the material has reached its technical service life, the modelling method considers which building parts are removed and how: i.e., demolition, deconstruction or disassembly. If demolition is necessary, the material needs processing before it can be recycled or disposed. Consequently, demolition costs include labor costs, processing costs of unsorted materials and transport costs. Deconstruction and disassembly 
are considered when a demountable building component is removed. In both cases, it is more efficient to recover and sort out materials. In the first case, it is possible to claim their residual material value. In the second case, it is possible to reuse them.

The calculations do not discount the costs and savings that are situated further in time. In contrast to conventional LCC [24], the current objective is not to make an investment consideration, but to assess affordability of housing through the building's service life.

Now all the input data are collected, everything is in place to calculate the LCC of the reference and the expandable house, both with conventional and alternative materials. Two relevant comparisons can be made (Figure 13): the reference house can be compared to the expandable house with conventional materials (comparison 1), and the expandable house with conventional materials can be compared to the expandable house with alternative materials (comparison 2). In comparison 1, the design approaches and housing alternatives can be compared. In comparison 2 , the alternative material choices can be compared.

\begin{tabular}{|c|c|c|}
\hline $\begin{array}{c}\text { Reference house } \\
\text { Conventional materials }\end{array}$ & $\begin{array}{c}\text { Expandable house } \\
\text { Conventional materials }\end{array}$ & $\begin{array}{l}\text { Comparison 1: comparison of housing } \\
\text { design approaches }\end{array}$ \\
\hline $\begin{array}{c}\text { Expandable house } \\
\text { Conventional materials }\end{array}$ & $\begin{array}{l}\text { Expandable house } \\
\text { Alternative materials }\end{array}$ & Comparison 2: comparison of material use \\
\hline
\end{tabular}

Figure 13. Scheme of two comparisons. Comparison 1 compares the housing design approaches and comparison 2 compares the material choices.

To increase transparency and traceability, a detailed calculation of the 'work from home' scenario applied to the reference house built with conventional materials is provided in Appendix E. Moreover, all resulting life cycle costs and total costs for all scenario narratives, housing design approaches, and material uses can be found in Supplementary Materials.

\section{Results}

\subsection{Initial Costs}

First, the initial costs are calculated and compared. This shows a clear difference between the initial cost of the expandable houses, i.e., the core houses, and the conventional house (Table 3). Building the core of the expandable house is more cost-efficient than the conventional design alternative; it is $39.5 \%$ lower when both are built with conventional materials. Of course, this is the result of the floor area of the core house which is much smaller $\left(60 \mathrm{~m}^{2}\right)$ than that of the reference house being $175.58 \mathrm{~m}^{2}$, whereas both offer sufficient space for, and fulfill the needs of, the two-person household every relevant scenario starts with. The initial cost of the core house built with alternative materials is even slightly lower than that of the core house built with conventional materials. According to the calculations, this is mainly due to the more manageable but less durable interior walls. They have a relatively low labor cost due to the speed with which they are installed.

Table 3. The initial construction costs of the three design alternatives.

\begin{tabular}{cc}
\hline Typology/Materials & Initial Cost \\
\hline $\begin{array}{c}\text { Reference house } \\
\text { (Conventional materials) }\end{array}$ & EUR 93,222.55 \\
\hline $\begin{array}{c}\text { Expandable house- } \\
\text { Conventional materials }\end{array}$ & EUR 56,363.53 \\
\hline $\begin{array}{c}\text { Expandable house- } \\
\text { Alternative materials }\end{array}$ & EUR 50,808.56 \\
\hline
\end{tabular}

\subsection{Comparison 1: Alternative Design Approaches}

Second, the LCC are calculated for each of the three scenario narratives (i.e., 'work from home', 'couple with children' and 'kangaroo dwelling'). From these results, the 
reference house can be compared to its expandable alternative made from conventional materials. In general, the life cycle cost of the expandable house (after 60 years) is lower than that of the conventional house. This statement is valid for each scenario (Figure 14) and can be explained by the fact that for every moment of its service life the expandable house's floor area can be kept lower than the one of the conventional houses although both fulfill the needs of each scenario at all times. After all, the expandable house allows more space efficient expansion, whereas the conventional house is generally oversized.

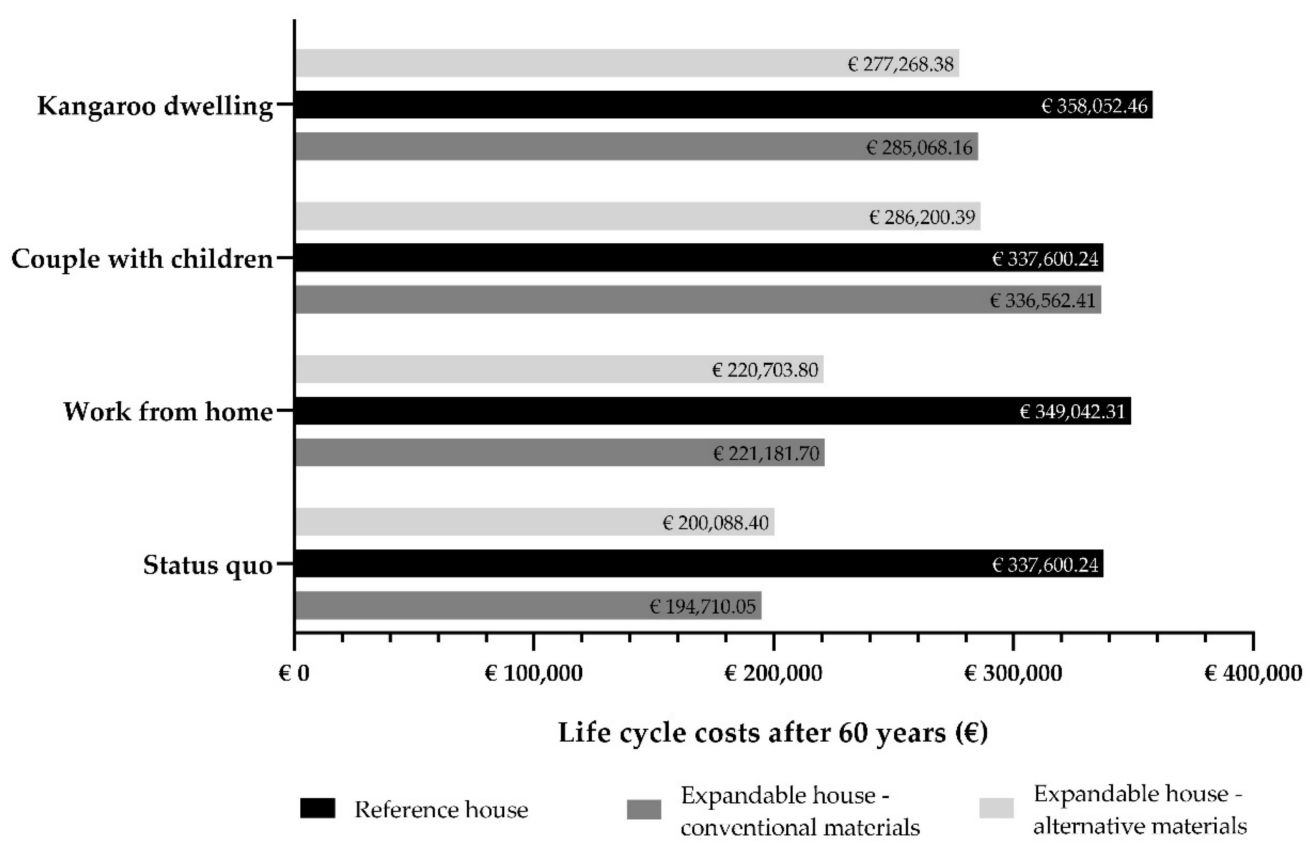

Figure 14. Life cycle costs after 60 years.

Only in the scenario narrative 'couple with children', the life cycle cost of both housing alternatives is almost equal. This has two reasons. First, the floor areas differ by $56 \mathrm{~m}^{2}$, which is smaller than in all other scenarios. Second, in the conventional house no changes are needed as the design is already based on this traditional household scenario and thus limits the necessary refurbishment costs. In contrast, the expandable house has to adapt three times. By choosing a life cycle of 60 years and variables of 15 years, the expandable house expands at 15 and 30 years due to the growing of the family, and shrinks at 45 years when the children are moving out.

To understand how each scenario affects the life cycle costs, a sensitivity analysis is made. All costs for a period of analysis that varies between 0 and 60 years are calculated (Figure 15). It is apparent from Figure 15 that the life cycle costs of the reference house are almost equal for each future scenario; the dashed lines are close to one another. To that end, for the reference house, the LCC will be more or less the same, and this during its whole life cycle, whatever the future would bring. The life cycle costs of the expandable house differ more; the full lines in Figure 15 are more dispersed. Decisions to make changes to the expandable house therefore have more impact on the life cycle cost. 


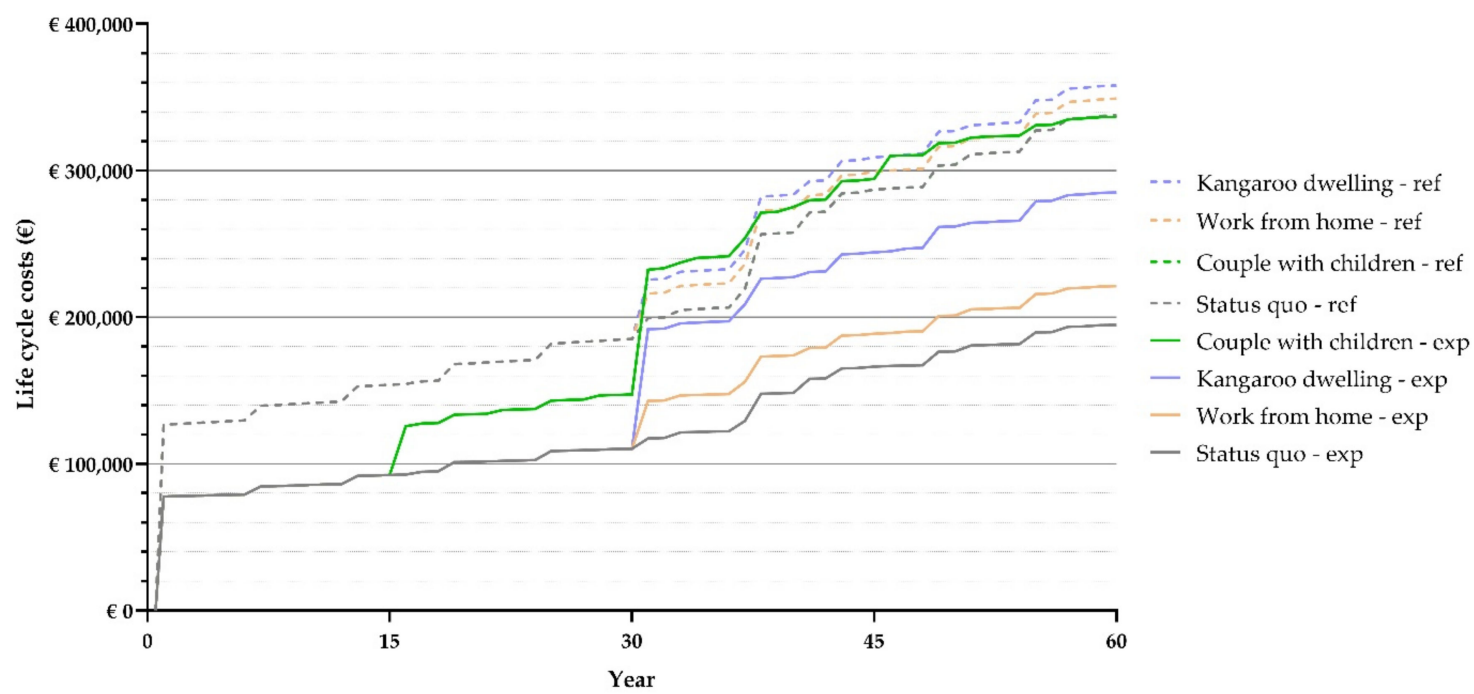

Figure 15. Sensitivity analysis of the life cycle cost for the scenarios over 60 years-Comparison 1.

If each scenario is analyzed for both the reference and the expandable house, it can be concluded that for each scenario the life cycle cost for the expandable house is lower than for the reference house. This is clearly visible for the scenarios 'status quo', 'work from home', and 'kangaroo dwelling'. However, for the 'couple with children' scenario, this is not always the case. The costs for the expandable house in this scenario are lower than those for the reference house until year 30. During the second expansion of the expandable house, where an additional floor on top is needed, significant costs must be incurred and the expandable house becomes more expensive than the reference house. However, over the years, the lines converge and cross again before year 60 . In the long run, this results in the expandable house being more cost-effective in every scenario as the life cycle costs, which is indicated in Figure 14 as well.

\subsection{Comparison 2: Alternative Material Choices}

When comparing the expandable house built with conventional materials with the expandable house built with alternative materials (comparison 2), the material choices are compared (Figure 16). For the scenarios 'couple with children' and 'kangaroo dwelling', the expandable house with alternative materials has a lower LCC after 60 years, whereas for the scenario 'work from home' and a status quo, the expandable house with conventional materials has a lower LCC after 60 years. Even the differences being relatively small, they must be interpreted. It can be observed that the cost differences are a result of the amount or the absence of expansions and the maintenance and repair costs of the different materials. For example, both the construction and the breakdown of the inner walls in conventional materials results in a higher cost than for the inner walls in alternative elements. Contrarily, the maintenance and repair costs are higher for the building elements in alternative materials. All those factors result in the converging of the LCC graph lines in the long run. More explanation on the integration of maintenance and repair cost is available in Appendix E. 


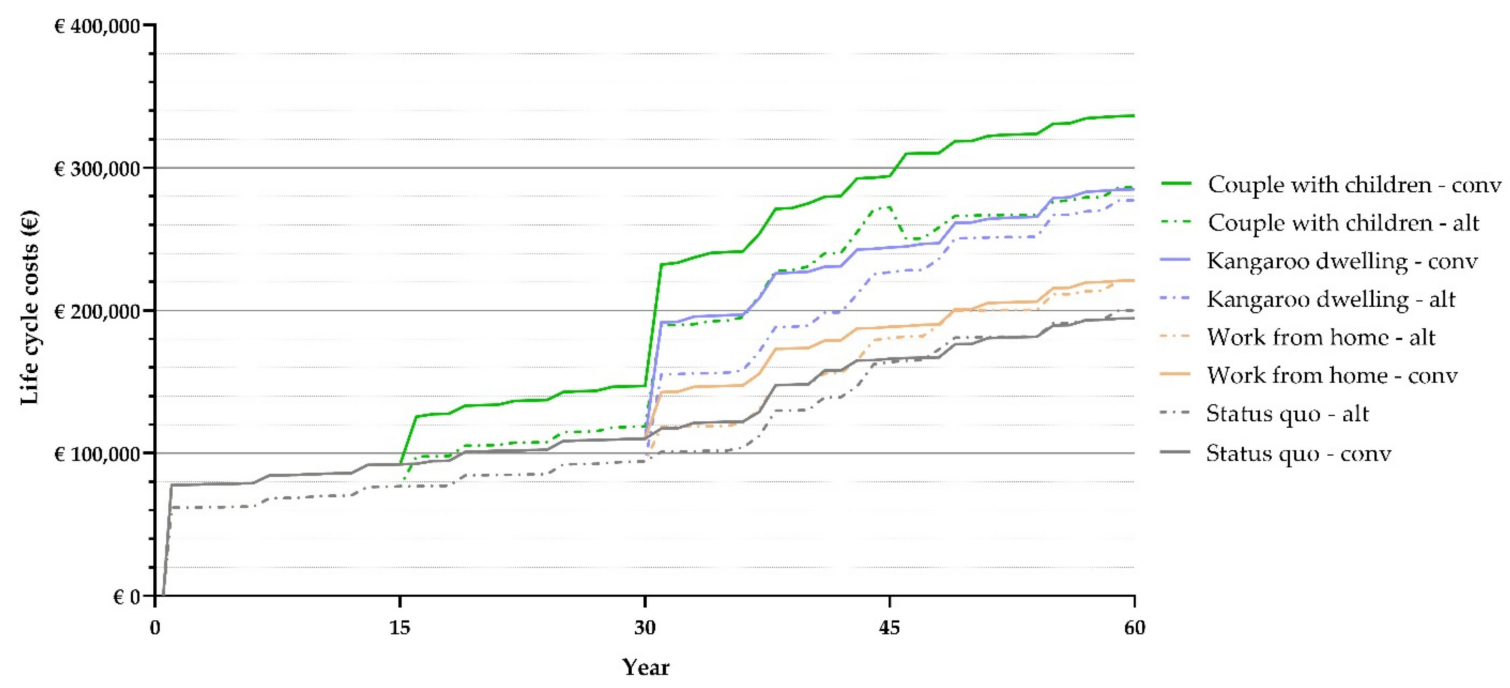

Figure 16. Sensitivity analysis of the life cycle cost for the scenario alternatives over 60 years—comparison 2.

What is interesting in the sensitivity analysis (Figure 16) is the decreasing line of the expandable house with alternative materials in the 'couple with children' scenario at 45 years. This is the consequence of the children moving out of the house, and the house shrinking again as a reaction to this change. The chart shows that shrinking a building constructed with alternative building materials, joint together with the use of reversible connections, and composed in layers according to the technical service life, can result in savings for the building owner. This is not the case for conventional building elements since their residual value is limited or even nil after demolition (Appendix E). This also explains the significant difference in LCC between both materializations after 60 years in Figure 14.

\section{Discussion and Conclusions}

The present study was set out to explore the financial potential of expandable houses as an answer to three challenges of the Flemish housing market, i.e., the affordability of housing, the environmental burden of construction and demolition activities, and the contradiction between a rigid housing supply and today's rapidly changing society. Therefore, the present exploration started with several case studies of expandable housing project to identify archetypical design approaches, and adopted a scenario planning method in combination with a research by design development to detail and model the service life of a relevant design for an expandable row house. By calculating the corresponding life cycle costs, it was possible to compare the short and long-term differences and to better understand the potential of expandable houses.

The LCC analysis shows that an expandable house following the 'core house' design concept is an interesting alternative, especially for households with a small budget. Compared to conventional housing, building a core house requires an almost $40 \%$ lower initial investment, and allows to spread other expenditures out over the building's service life. Moreover, when using reversible connections and manageable materials to facilitate the anticipated extensions, the initial costs are even slightly lower. Although, all in all, the life cycle costs do not differ much. Nevertheless, when the house shrinks and building elements are demountable, they provide an additional financial benefit: their residual value.

These promising results must, however, be treated with caution, as a building design cannot warrant that the occupants will use, or even be able to enjoy, the possibility of expanding or shrinking their house. Historic cases such as the Nakagin Capsule Tower have already shown that socio-economic aspects might overrule the financial and technical potential of a building design [9]. Therefore, practical concerns about the building management and recurrent project costs and hindrances, including refurbishment time and 
accessibility, should also be considered when designing expandable houses. Prefabricated modules seem to be promising in this regard. Therefore, it must be noted that the outcomes of this exploration cannot be generalized but must be verified for every expandable housing project, its specific context and envisioned user. As a result, a different detailing, that combines for example conventional external wall elements with alternative interior walls, floors and roofs could decrease the initial and the life cycle impact in a scenario with less demanding refurbishments [16].

Further, it is difficult to compare these findings to a benchmark as there are few LCC studies combined with a sustainability or circularity assessment, despite researchers stating that it might be the most reliable way of selecting sustainability improvement strategies for buildings [68]. There are multiple reasons for this. First, buildings are challenging to evaluate and to compare to other buildings: they are large in scale, complicated in materials and very diverse in design as none has exactly the same functional, technical and aesthetic performance compared to another. Second, buildings and building layers are in contrast with what is assumed in most LCC and LCA studies-functionally dynamic due to the limited service-life of their components and the changing user requirements. The idea that a building can thus be defined as the sum of a series of components with continuous properties over time must be questioned. In this paper we did so by putting the scenarios forward, and let them define the needs and functionality of the building design alternatives that are compared. This must however be theorized and evaluated further.

Moreover, when performing a LCC, many factors need to be taken into account and used as input, whereas one change in input can result in a large change in final LCC. For example, the initial cost of the core house built with alternative materials is lower than the core house built with conventional materials. This is apparently mainly due to the interior walls. However, this finding does not support previous research conducted by Buyle et al. [50], in which they compared different inner wall assemblies, including demountable wall assemblies. Their results showed that for the demountable inner walls, the initial cost is 31-69\% higher than that of the cheapest conventional alternative. To find out why this differs, a thorough analysis should be done.

Finally, it must be discussed that in contrast to the reference house, the core house design approach, i.e., a house that entails the minimum spaces required, is smaller and contains less materials, and this for every scenario narrative. Although it might seem impossible to compare a house that grows gradually to one that is much bigger from its completion onwards, both do fulfill at each moment of their service life the spatial and functional needs of each scenario narrative. The perceived incomparability is only the result of a different design approach, which is exactly what this exploration wanted to compare as objectively as possible; this in contrast to other LCC studies which define functional equivalence only at the level of components and not at the level of the whole building. The scenario-based modelling method that was adopted in this exploration allowed us to make this comparison by considering in the LCC cleaning and maintenance costs of hardly used spaces, but also by including future refurbishments and reuse possibilities. Here is also a link to be made to the first principle of circularity in building design: reduce. The 'core house' concept answers exactly to this often-mentioned but rarely discussed principle of a circular economy wherein the 'end-of-life' is not the focal point to intervene as designers, but wherein designing out waste is key [17].

To conclude, this exploration supports the proposition that designing expandable houses might be a catalyst for sustainable, circular housing development and that households could benefit from its social, economic and ecological qualities. It requires however a dynamic perspective on evaluating their life-cycle impact. 
Supplementary Materials: The following are available online at https://www.mdpi.com/article/10 $.3390 /$ su13126974/s1.

Author Contributions: Conceptualization, C.C. and W.G.; methodology, C.C. and W.G.; data curation, C.C.; writing-original draft preparation, C.C.; writing-review and editing, C.C. and W.G.; visualization, C.C.; supervision, W.G. and N.D.T. All authors have read and agreed to the published version of the manuscript.

Funding: This research was funded by Fonds Wetenschappelijk Onderzoek (FWO), grant number $1 \mathrm{~S} 55518 \mathrm{~N}$.

Data Availability Statement: The data presented in this study are available in Supplementary Materials.

Conflicts of Interest: The authors declare no conflict of interest.

\section{Appendix A}

Next to the design of the reference house (Figure 9 in Section 3.3.2.) in its initial stage, the adaptations and expansions for the 'work from home' (Figure A1) and 'kangaroo dwelling' (Figure A2) scenario narratives are designed. The adaptations for the 'couple with children' scenario narrative are not included as the initial reference house is designed for this purpose.
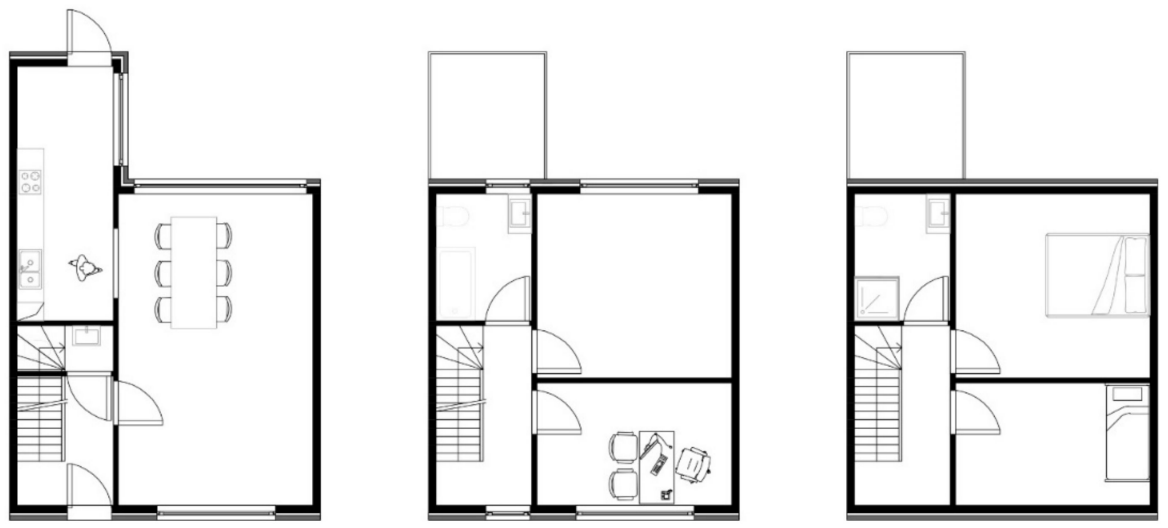

Figure A1. Floor plans of the reference house for the scenario 'work from home'.
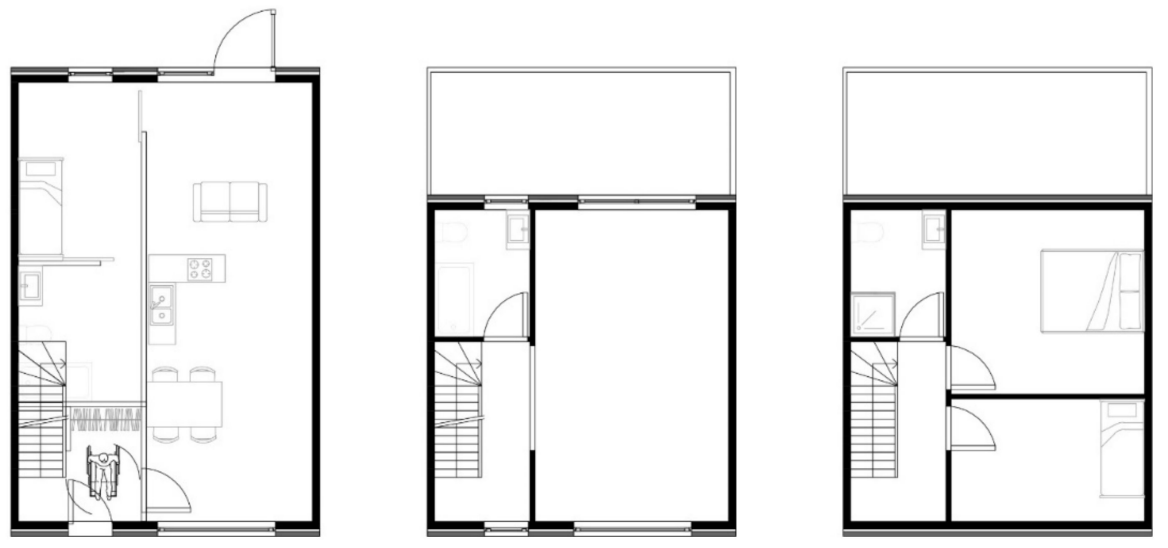

Figure A2. Floor plans of the reference house for the scenario 'kangaroo dwelling'.

\section{Appendix B}

Next to the detailing of the exterior wall (Figure 10 in Section 3.3.1.), a representative composition and materialization of the inner wall, the ground floor, the floors and the roof are developed. These details are based on [27]. 


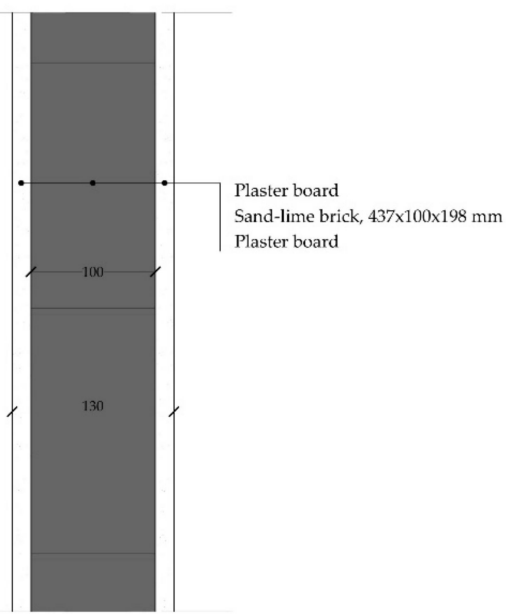

Figure A3. Detail of the inner wall in conventional materials.

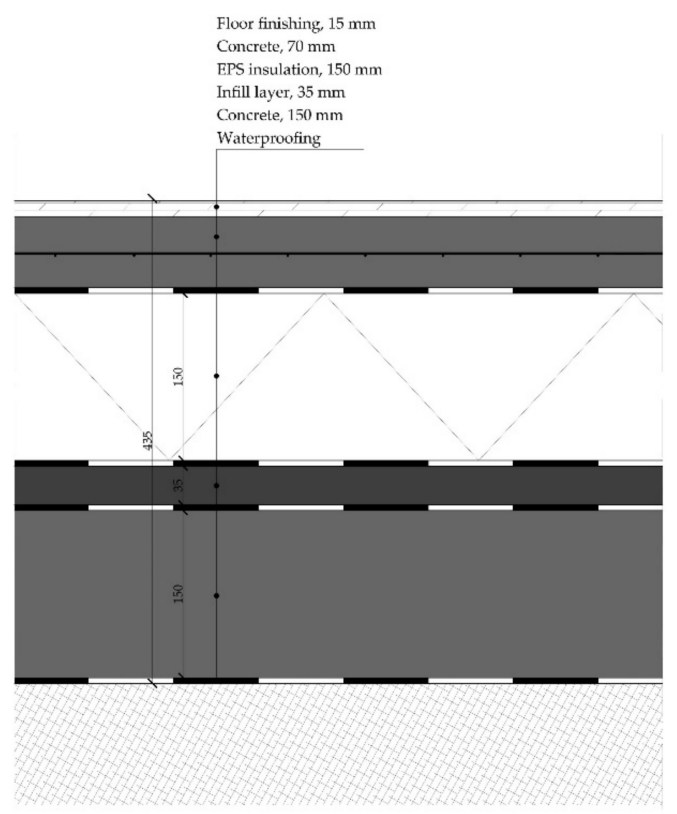

Figure A4. Detail of the ground floor in conventional materials.

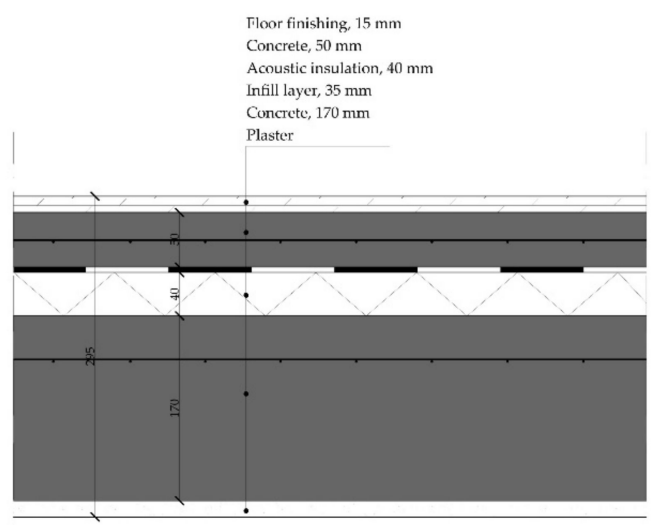

Figure A5. Detail of the floor in conventional materials. 


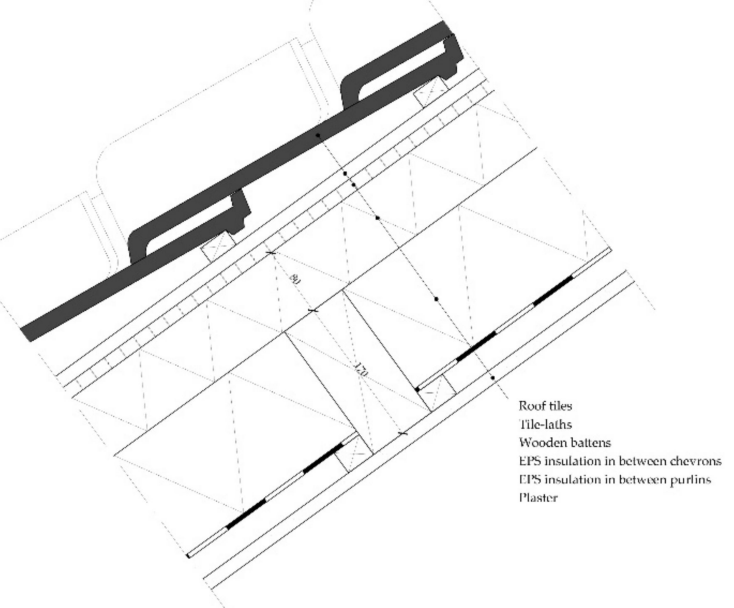

Figure A6. Detail of the roof in conventional materials.

\section{Appendix C}

Next to the design of the core house (Figure 11 in Section 3.3.2.), the adaptations and expansions of the expandable house for the 'work from home', the 'couple with children' and the 'kangaroo dwelling' scenarios are designed (Figures A7-A10). The adaptation towards the 'couple with children' scenario narrative occurs in two expansions (Figures A8 and A9).

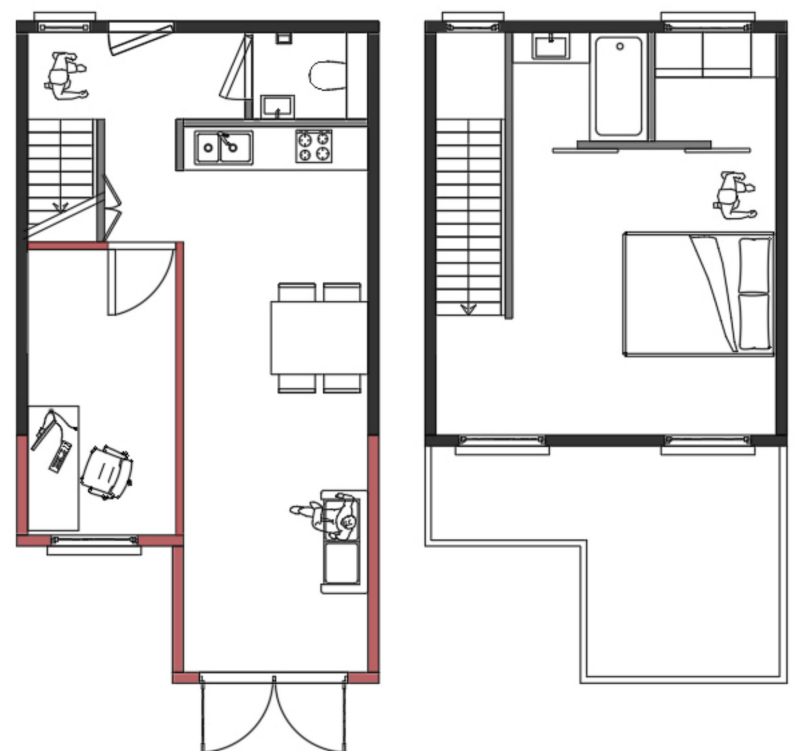

Figure A7. Floor plans of the expandable house for the scenario 'work from home'. The building elements in red are the newly added elements. 

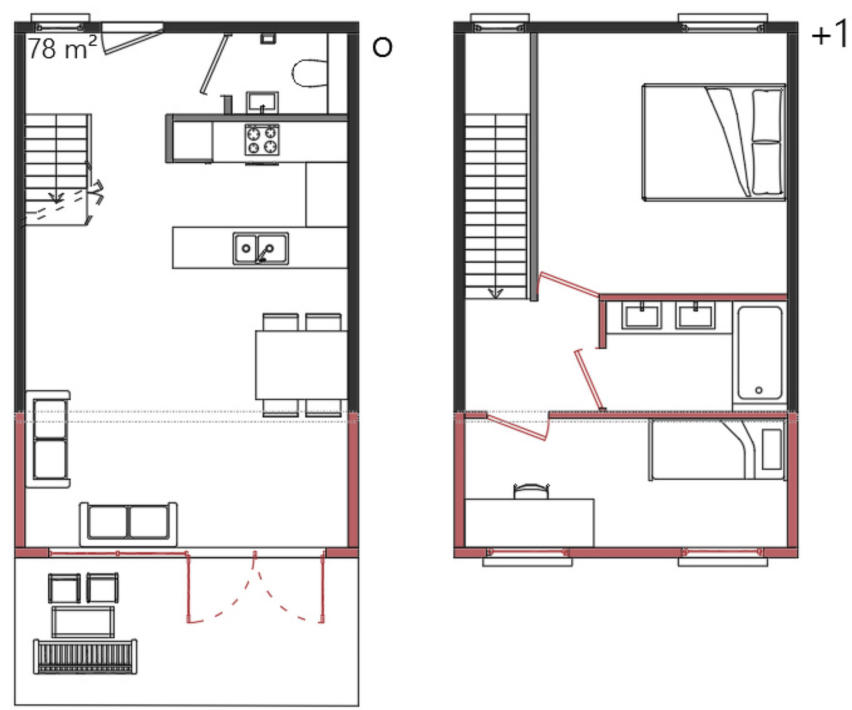

Figure A8. Floor plans of the expandable house for the scenario 'couple with children' (first expansion). The building elements in red are the newly added elements.
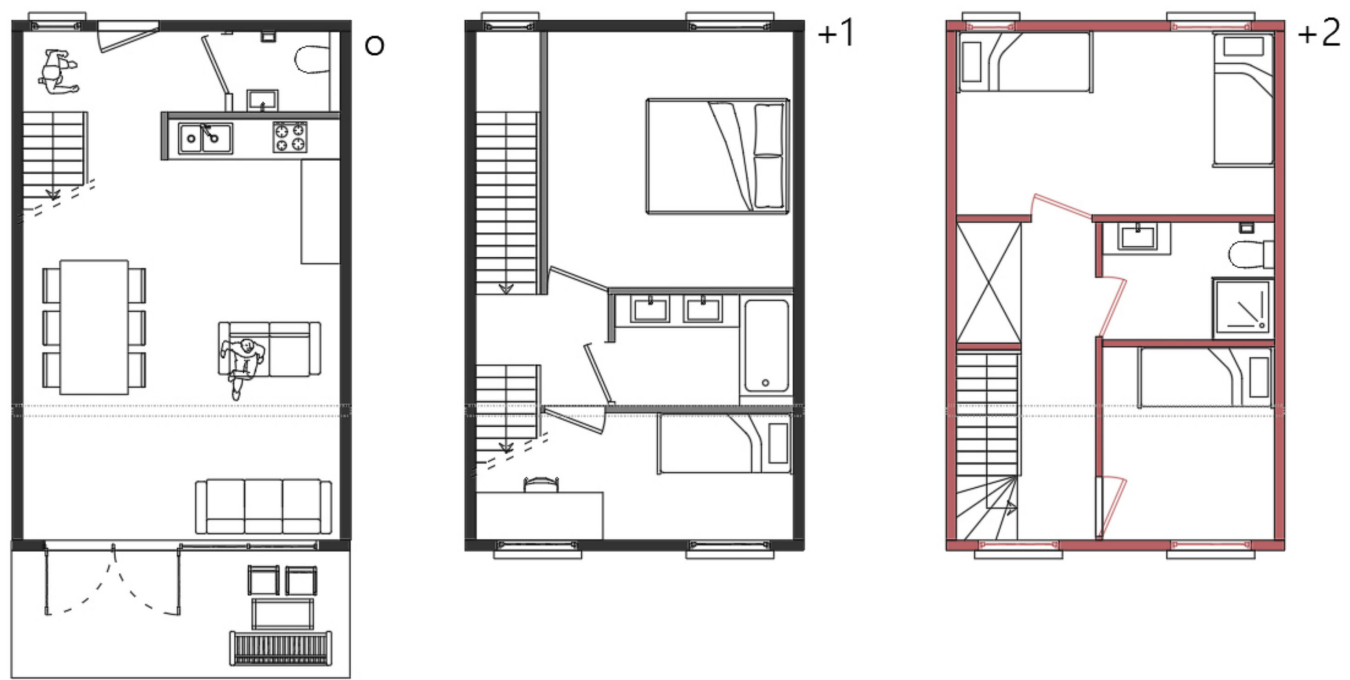

Figure A9. Floor plans of the expandable house for the scenario 'couple with children' (second expansion). The building elements in red are the newly added elements. 


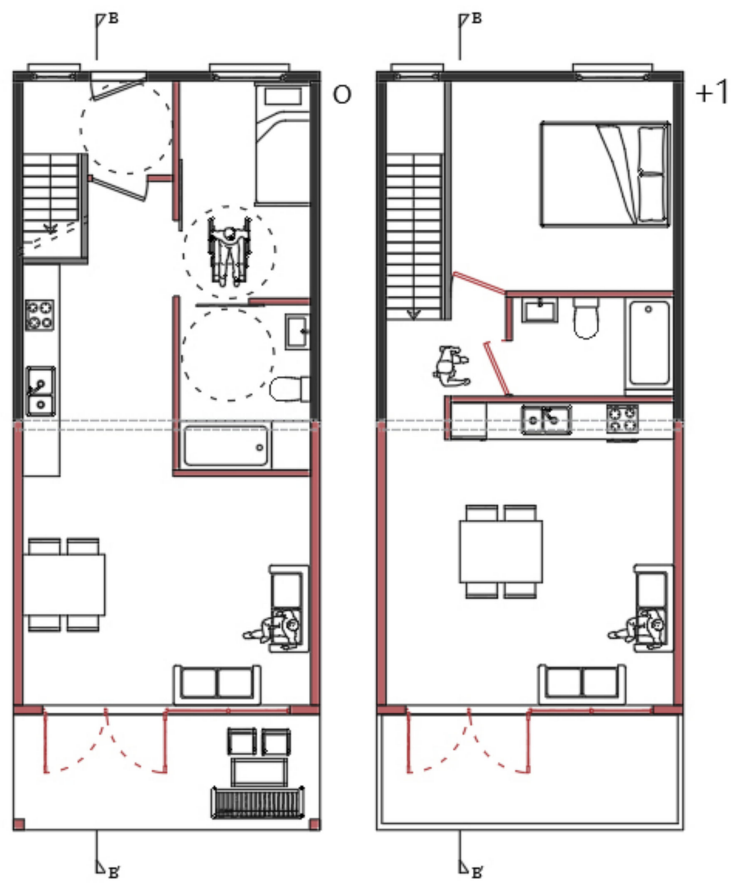

Figure A10. Floor plans of the expandable house for the scenario 'kangaroo dwelling'. The building elements in red are the newly added elements.

\section{Appendix D}

Next to the detailing of the exterior wall (Figure 12 in Section 3.3.2.), the composition and materialization of the inner wall, the ground floor, the floors and the roof are developed. These details are based on [16].

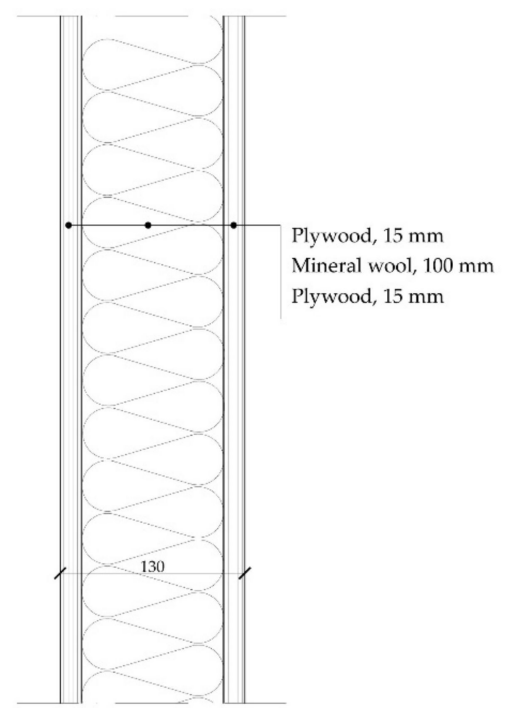

Figure A11. Detail of the inner wall in alternative materials. 


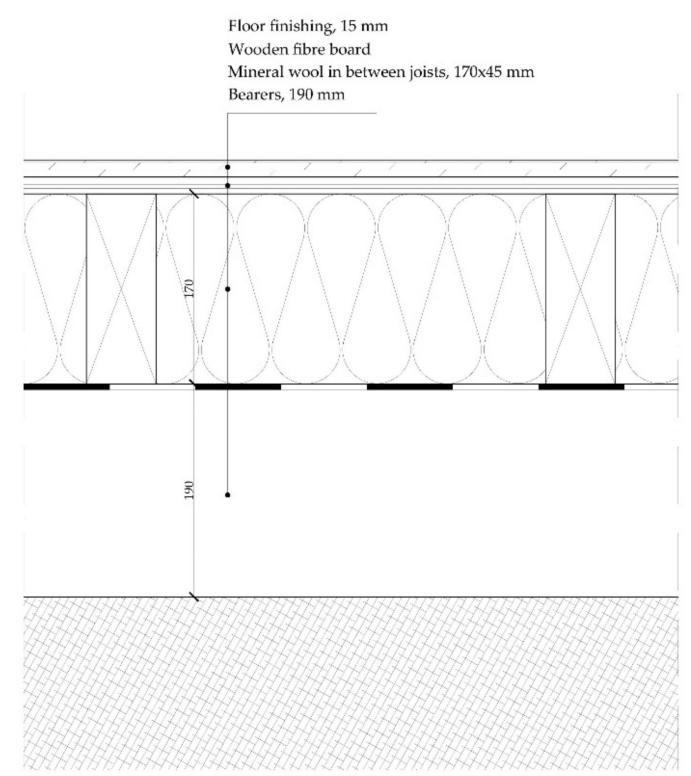

Figure A12. Detail of the ground floor in alternative materials.

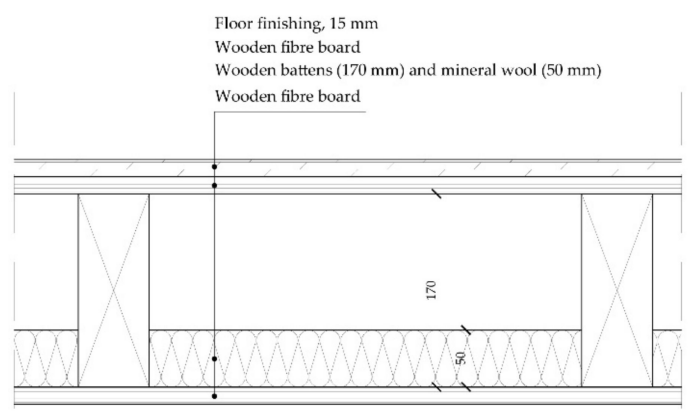

Figure A13. Detail of the floor in alternative materials.

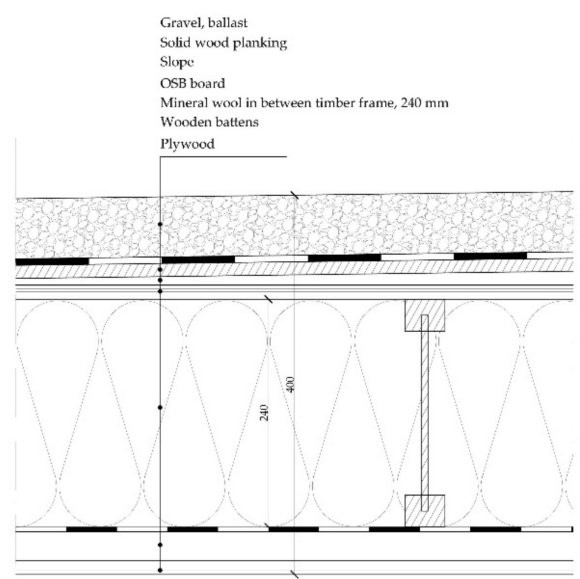

Figure A14. Detail of the roof in alternative materials. 


\section{Appendix E}

Example of the calculation method: the case for the 'work from home' scenario applied to the reference house built with conventional materials.

For the calculation of the life cycle costs, the scenario-based LCC analysis method and tool, developed by Galle [24], is used. First, the building elements, both in conventional and alternative materials, that have been defined in Sections 3.3.1 and 3.3.2, are generated in the tool. Figure A15 shows how the building elements are defined in the model, and this for the inner wall in conventional materials. The materials are inserted in their correct layering, the building element is defined and the thickness is entered. As mentioned in Section 4, the materials and their maintenance cycles and their costs are derived from ASPEN [54]. The materials can thus be selected from this database, which is done in this case. It is also possible to add a new material that can be defined by the user.

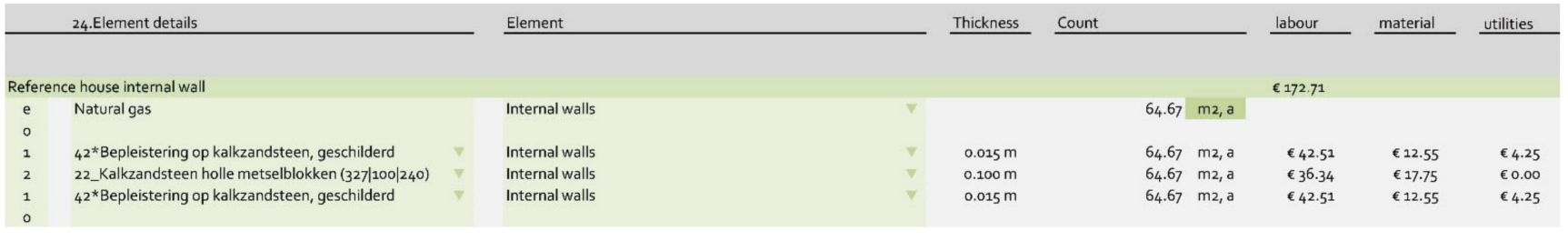

Figure A15. Defining the building elements in the LCC model.

Further, the user needs to assign repair interventions to each building element layer. Repairs are defined by their periodicity, extensity and intensity (Table A1). The actions that causes repairs are not predictable. Therefore, the obtained figures of the repairs should thus be taken into account with some uncertainty.

Table A1. Defining the repairs of the building element layers.

\begin{tabular}{ccc}
\hline & Definition & Descriptive Indicators \\
\hline Periodicity & $\begin{array}{c}\text { Number of years between two } \\
\text { repairs }\end{array}$ & $\begin{array}{c}\text { Rare, seldom, occasional, } \\
\text { frequent }\end{array}$ \\
\hline Extensity & $\begin{array}{c}\text { Share of elements that is } \\
\text { subjected to damage }\end{array}$ & $\begin{array}{c}\text { Ubiquitous, widespread, } \\
\text { common, local }\end{array}$ \\
\hline Intensity & $\begin{array}{c}\text { Fraction per element unit that } \\
\text { has to be replaced }\end{array}$ & $\begin{array}{c}\text { Complete, segmental, partial, } \\
\text { fragmental }\end{array}$ \\
\hline
\end{tabular}

When the service life is reached, the building element needs to be disassembled, demolished or deconstructed. If demolition is necessary, the material needs processing before it can be recycled or disposed. Consequently, demolition costs include labor costs, processing costs of unsorted materials and transport costs. In the case of deconstruction, it is more efficient to sort out different materials. Disassembly is considered when a demountable building component is removed but has not yet reached its estimated service life. This is the case for the alternative building elements considered in this research (Section 3.3.2.). The large advantage is that materials can be reused and thus have a larger residual value. Furthermore, it is possible to make a distinction between sorted and unsorted materials and between recyclable and unrecyclable materials.

When all the building elements and materials and their properties are set, the measurements from the floor plans and other technical drawings are imported from the digital BIM model. For this example, this is completed for the core house and for the 'work from home' scenario of the reference house. This way, it is calculated how much material (in $\mathrm{m}^{2} / \mathrm{m}^{3}$ ) is added and removed to transform to the initial core house to the 'work from home' extension.

For every transformation scenario and corresponding inventory, the total life cycle cost is then calculated by looping all life cycle stages of all modelled building elements. 
The model gives two types of outcomes. The first outcome of the LCC model is an overview of the life cycle costs per building element, per life cycle stage and per building state. In this example, these are: the elements that remain in place during the 60 years $(0-60)$, the elements that are demolished or disassembled during the transformation $(0-30)$ and the elements that are added during the transformation (30-60) (Figure A16). These costs are shown for each Life Cycle Assessment (LCA) stage, where A is initial cost, B is recurring costs and C is end-of-life costs. The LCA stages are defined according to EN 15978 and EN 15804 (Figure A17). The resulting life cycle costs for the other scenario narratives can be found in Supplementary Materials.

\begin{tabular}{|c|c|c|c|c|c|c|c|c|c|c|c|c|c|c|c|c|}
\hline \multicolumn{17}{|l|}{ Scenario narrative: work from home } \\
\hline & Period of analysis_ $T$ & & 60 & & & & & & & & & & & & & \\
\hline Reference house Ground floor & $0-60$ & 57.68999863 & $13,337.92773$ & 0 & 958.1996 & $96 \quad 21,901.4$ & 4 5,821.673 & $36,194.301$ & & 0 & 0 & 0 & 0 & & $7,071.857$ & $55,285.35938$ \\
\hline Reference house Ground floor & $30-60$ & 8.840000153 & 0 & $2,789.042$ & 263.39179 & $79 \quad 1,668.83$ & 1343.77675 & 0 & & 0 & 0 & 0 & 0 & 0 & $1,083.641$ & $5,648.681152$ \\
\hline Reference house Ground floor & & & $13,337.92773$ & $2,789.042$ & $21,021.591$ & $91 \quad 23,570.23$ & $135,865.45$ & 6,194.301 & & 0 & 0 & 0 & 0 & 0 & $8,155.498$ & $60,934.03906$ \\
\hline Reference house Exterior wall Brickwork & 0.30 & 9.960000038 & $2,326.556396$ & 0 & 98.4834 & $34 \quad 673.2094$ & 4266.1105 & 0 & & 0 & 0 & $\begin{array}{ll}0 & 1,266.64\end{array}$ & & 0 & 0 & $4,631.003418$ \\
\hline Reference house Exterior wall Brickwork & $0-60$ & 59.31000137 & $13,854.22363$ & 0 & $1,032.017$ & $179,940.005$ & $54,765.921$ & $5,222.103$ & & 0 & 0 & $0 \quad\{\quad>>>>0$ & 0 & & $8,573.304$ & $43,387.57422$ \\
\hline Reference house Exterior wall Brickwork & $30-60$ & 6.400000095 & & $2,031.835$ & 548.07996 & 66527.2861 & $1 \quad 203.746$ & 0 & & 0 & 0 & 0 & 0 & & 925.1246 & $3,736.071533$ \\
\hline Reference house Exterior wall Brickwork & & & $16,180.78027$ & $2,031.835$ & $\begin{array}{ll}5,178.58 \\
-1,19\end{array}$ & $58 \quad 11,140.5$ & $5,235.778$ & $5,222.103$ & & 0 & 0 & 0 1,266.64 & & & $9,498.429$ & $51,754.64844$ \\
\hline Reference house Exterior wall & $0-60$ & 111.4100037 & $14,888.83301$ & 0 & $19,38.577$ & 77 17,873.39 & $193,621.309$ & $9,809.383$ & & 0 & 0 & 0 & 0 & 0 & $10,261.37$ & $58,392.85156$ \\
\hline Reference house Exterior wall & $30-60$ & 6.900000095 & 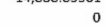 & $1,221.192$ & 251.83621 & $21 \quad 542.6627$ & 788.88271 & 0 & 0 & 0 & 0 & 0 & 0 & 0 & 635.5212 & $2,540.095215$ \\
\hline Reference house Exterior wall & & & $14,888.83301$ & $1,221.192$ & $21,990.413$ & $13 \quad 18,416.05$ & 5 3,710.191 & $9,809.383$ & & 0 & 0 & 0 & 0 & 0 & $10,896.89$ & $60,932.94531$ \\
\hline Reference house Windows in facade & $0-30$ & 10.43999958 & $2,770.158936$ & 0 & 0703.8381 & 0 & 0 & 0 & 0 & 0 & 0 & $\begin{array}{lll}0 & 109.542\end{array}$ & & 0 & 0 & 3,583.539551 \\
\hline Reference house Windows in facade & $0-60$ & 18.07999992 & $4,797.36377$ & & 2,144.993 & 0 & 161.4359 & $7,786.532$ & & 0 & 0 & 0 & 0 & & 202.8063 & $15,093.12988$ \\
\hline Reference house Windows in facade & $30-60$ & 5.300000191 & $4,157.30371$ & $2,005.887$ & $7 \quad 271.4742$ & 0 & 0 & 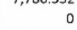 & 0 & 0 & 0 & 0 & 0 & & 59.45096 & $2,336.812012$ \\
\hline Reference house Windows in facade & & & $7,567.522461$ & $2,005.887$ & $73,120.305$ & 0 & 161.4359 & $7,786.532$ & & 0 & 0 & $0 \quad 109.542$ & & 0 & 262.2573 & $21,013.48242$ \\
\hline Reference house internal wall & $0-30$ & 19.97999954 & $3,450.745605$ & 0 & 0 & $0 \quad 3,593.068$ & 8285.6487 & 0 & 0 & 0 & 0 & 0814.526 & & 0 & 0 & $8,143.989258$ \\
\hline Reference house internal wall & $0-60$ & 44.68999863 & $7,718.409668$ & 0 & & $\begin{array}{ll}0 & 19,570.43 \\
0\end{array}$ & $\begin{array}{ll}13 & 1,939.798 \\
13\end{array}$ & $4,318.659$ & & 0 & 0 & 0 & 0 & & $2,085.737$ & $35,633.03125$ \\
\hline Reference house internal wall & $30 \cdot 60$ & 20.54000092 & & $4,630.875$ & & $\begin{array}{ll}0 & 4,308.284 \\
\end{array}$ & $4 \quad 346.9748$ & 30 & & 0 & 0 & 0 & 0 & 0 & 958.6269 & $10,244.76074$ \\
\hline Reference house internal wall & & & $11,169.15527$ & $4,630.875$ & 0 & $\begin{array}{ll}0 & 2,7471.78\end{array}$ & $82,572.421$ & $4,318.659$ & & 0 & 0 & o 814.526 & & 0 & $3,044.364$ & $54,021.78125$ \\
\hline Reference House Floors & $0-60$ & 105.4000015 & $20,856.55273$ & 0 & & & $56,203.888$ & $14,381.06$ & & 0 & 0 & 0 & 0 & 0 & $6,648.311$ & $74,995.66406$ \\
\hline Reference House Floors & & & $20,856.55273$ & 0 & 0 & o $26,905.85$ & $56,203.888$ & $14,381.06$ & & 0 & 0 & 0 & 0 & & $6,648.311$ & $74,995.66406$ \\
\hline Reference House Roof & $0-60$ & 57.20000076 & $9,221.78418$ & 0 & 950.061 & $511,571.511$ & $11,556.944$ & $+2,893.785$ & & 0 & 0 & 0 & 0 & 0 & $6,686.329$ & $22,880.41406$ \\
\hline Reference House Roof & $30-60$ & 10.14000034 & & $1,068.924$ & 472.71411 & 1199.89469 & 982.49453 & 30 & & 0 & 0 & 0 & 0 & 0 & $1,185.304$ & $2,509.331299$ \\
\hline Reference House Roof & & & $9,221.78418$ & $1,068.924$ & $41,022.775$ & $751,671.405$ & $5 \quad 1,639.439$ & $2,893.785$ & & 0 & 0 & 0 & 0 & 0 & $7,871.632$ & $25,389.74609$ \\
\hline & & & $93,222.55566$ & $13,747.76$ & $68,333.665$ & $65109,175.8$ & $\begin{array}{l}825,388.6 \\
.\end{array}$ & $50,605.83$ & & 0 & 0 & o $2,190.71$ & & & $46,377,38$ & $349,042.3066$ \\
\hline
\end{tabular}

Figure A16. The first outcome of the LCC model is an overview of the life cycle costs per building element, per life cycle stage and per building state. The blue row indicates the cost of the whole house per life cycle stage. All values in the life cycle stages are in euros.

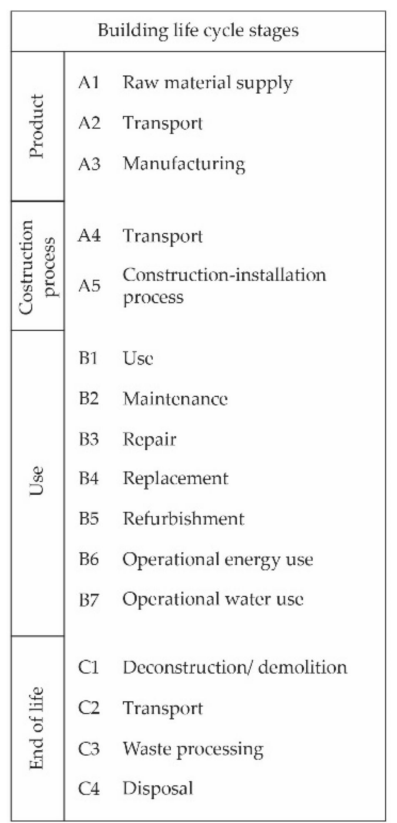

Figure A17. A building's Life Cycle Assessment (LCA) stages according to EN 15978 and EN 15804. 
The initial cost of the reference house is shown at the bottom of the 'A4-5' column (EUR 93,222.55) and the total cost for the 'work from home' scenario is shown in the bottom right corner (EUR 34,9042.31). These numbers are used to generate Table 3 and Figure 14.

The second type of outcome is an overview of the total costs for each year for each building element and, by summing them all up (in blue), for the house in general (Figure A18). The resulting total costs for the other scenario narratives can be found in Supplementary Materials.

Scenario narrative: work from home

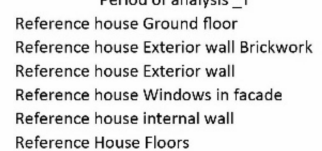

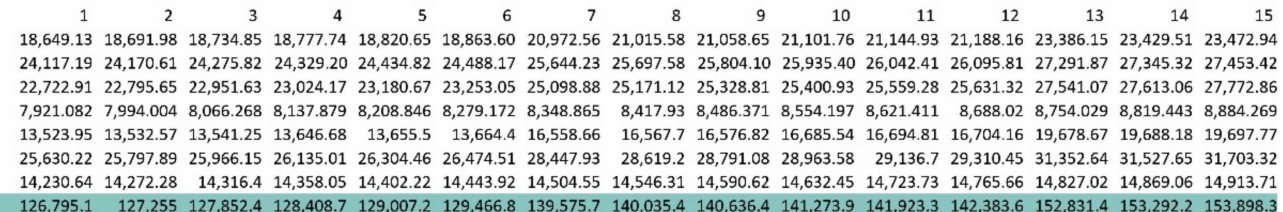

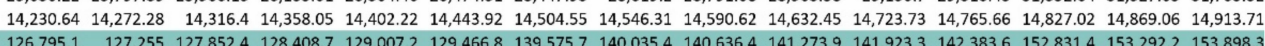

Figure A18. The second outcome of the LCC model is an overview of the total costs for each year for each building element and, by summing them all up, for the house in general. The blue row indicates the cost of the whole house per year. All values are in euros.

From these results, i.e., the sensitivity analyses, the graphs in Figures 15 and 16 were generated. The initial and the LCC for other scenarios, housing design approaches, and materials are calculated in the same manner. The detailed results from the LCC model are given in a separate spreadsheet, wherein the data for each of the scenarios and material choices are available.

\section{References}

1. Friedman, T.L. Hot, Flat, and Crowded: Why We Need a Green Revolution-And How It Can. Renew. America, 1st ed.; Farrar, Straus and Giroux: New York, NY, USA, 2008; ISBN 978-0-374-16685-4.

2. OVAM. Materiaalbewust Bouwen in Kringlopen: Preventieprogramma Duurzaam Materialenbeheer in de Bouwsector 20142020. 2013. Available online: https:/ /www.ovam.be/sites/default/files/FILE1387460657455130930_Materiaalbewust_bouwen_ kringlopen_2014_2020.pdf (accessed on 28 August 2020).

3. Friedman, A. Fundamentals of Sustainable Dwellings; Island Press: Washington, DC, USA, 2012; ISBN 978-1-59726-807-3.

4. Merrild, H. Building a Circular Future; Guldager, K., Sommer, J., Eds.; KLS PurePrint: Hvidovre, Denmark, 2016; ISBN 978-87998670-1-1.

5. United Nations Environment Programme. 2020 Global Status Report for Buildings and Construction: Towards a Zero-Emission, Efficient and Resilient Buildings and Construction Sector; United Nations Environment Programme: Nairobi, Kenya, 2020 ; p. 80.

6. IEA. Global Status Report for Buildings and Construction 2019; IEA: Paris, France, 2019.

7. European Commission. EU Circular Economy Action Plan.: A New Circular Economy Action Plan. for a Cleaner and More Competitive Europe; European Commission: Brussels, Belgium, 2020.

8. Winters, S.; Heylen, K.; Pannecoucke, I.; De Decker, P. De Vlaamse Sociale Huur. Een Vertaling van de Recentste Gegevens Naar Beleidsvragen; Steunpunt Wonen: Leuven, Belgium, 2016; p. 48.

9. Vermeiren, K.; Vervoort, P.; Pisman, A. Ruimterapport Vlaanderen (RURA): Een Ruimtelijke Analyse van Vlaanderen; Departement Omgeving: Brussels, Belgium, 2018.

10. Englert, M.; Luyten, S.; Mazina, D.; Yannart, M. Welzijnsbarometer 2015: Samenvatting. Available online: https://www.ccc-ggc. brussels/nl/observatbru/publications/2015-welzijnsbarometer (accessed on 11 January 2018).

11. Housing Europe. Social Housing in Europe Belgium; CECODHAS Housing Europe's Observatory: Brussels, Belgium, 2011.

12. Salama, W. Design of concrete buildings for disassembly: An explorative review. Int. J. Sustain. Built Environ. 2017, 19, 617-635. [CrossRef]

13. Till, J.; Schneider, T. Flexible Housing: The Means to the End. Archit. Res. Q. 2005, 9, 287-296. [CrossRef]

14. Bach, A.; Katari Gupta, P.; Haughey, R.; Kelly, G.; Pawlukiewicz, M.; Pitchford, M. Ten Principles for Developing Affordable Housing. 2007. Available online: https://americas.uli.org/ten-principles-for-developing-affordable-housing/ (accessed on 28 April 2018).

15. Galle, W.; Herthogs, P. Veranderingsgericht Bouwen: Gemeenschappelijke Taal; Openbare Vlaamse Afvalstoffen Maatschappij: Mechelen, Belgium, 2015.

16. Vandenbroucke, M.; Galle, W.; De Temmerman, N.; Debacker, W.; Paduart, A. Using life cycle assessment to inform decisionmaking for sustainable buildings. Buildings 2015, 5, 536-559. [CrossRef] 
17. Kirchherr, J.; Reike, D.; Hekkert, M. Conceptualizing the circular economy: An analysis of 114 definitions. Resour. Conserv. Recycl. 2017, 127, 221-232. [CrossRef]

18. Paduart, A. Re-Design for Change: A 4-Dimensional Approach towards a Dynamic and Sustainable Building Stock. Ph.D. Thesis, Vrije Universiteit Brussel, Brussels, Belgium, 2012.

19. Friedman, A. The Adaptable House Designing For Change; McGraw Hill: New York, NY, USA, 2002.

20. Schwartz, P. The Art of the Long View: Scenario Planning Protecting Your Company against an Uncertain Future; Century Business: London, UK, 1991; ISBN 978-0-7126-9831-3.

21. Amoako, C.; Frimpong Boamah, E. Build as you earn and learn: Informal urbanism and incremental housing financing in Kumasi, Ghana. J. Hous. Built Environ. 2017, 32, 429-448. [CrossRef]

22. Mora, R.; Greene, M.; Gaspar, R.; Moran, P. Exploring the mutual adaptive process of home-making and incremental upgrades in the context of chile's progressive housing programme (1994-2016). J. Hous. Built Environ. 2020, 35, 243-264. [CrossRef]

23. Starterswoning Op de Groei: Huis in Antwerpen-FELT Architecture \& Design. Available online: https:/ / www.dearchitect.nl/ projecten/starterswoning-op-de-groei-huis-in-antwerpen-felt-architecture-design (accessed on 16 March 2021).

24. Galle, W. Scenario Based Life Cycle Costing: An Enhanced Method for Evaluating the Financial Feasibility of Transformable Building. Ph.D. Thesis, Vrije Universiteit Brussel, Brussels, Belgium, 2016.

25. Hauberg, J. Research by Design—a Research Strategy. Revista Lusófona de Architectura e Educacao 2011, 5, 46-56.

26. VMSW C2008. Leidraad Voor Bouwheren en Ontwerpers van Sociale Woningen; Vlaamse Maatschappij voor Sociaal Wonen: Brussels, Belgium, 2014.

27. Van der Veken, J.; Creylman, J.; Lenaerts, T. Studie Naar de Kostenoptimale Niveaus van de Minimumeisen Inzake Energieprestaties van Nieuwe Residentiële Gebouwen; Thomas More Kempen/ KU Leuven: Geel, Belgium, 2015.

28. Galle, W.; Cambier, C.; De Temmerman, N.; Elsen, S.; Lanckriet, W.; Poppe, J.; Tavernier, I.; Vandervaeren, C. Building a Circular Economy: Buildings, a Dynamic Environment; Vrije Universiteit Brussel: Brussels, Belgium, 2019; ISBN 978-94-91912-16-0.

29. Vrijders, J.; Decuypere, R. Levenscycluskostenanalyse (LCC) Voor de Beoordeling van de Economische Prestatie van Duurzame Gebouwen. Available online: http:/ / www.wtcb.be/homepage/index.cfm?cat=projects\&proj=89 (accessed on 17 June 2021).

30. Statistiek Vlaanderen Eigendomsstatuut. Available online: https://www.statistiekvlaanderen.be/nl/eigendomsstatuut (accessed on 29 March 2021).

31. Heylen, K.; Vanderstraeten, L. Wonen in Vlaanderen Anno 2018; Gompel\&Svacina: Oud-Turnhout, Belgium, 2019; ISBN 978-946371-140-1.

32. Loko Architecten. "Ik bouw betaalbaar in Nijmegen" (IbbN). 2013. Available online: https://loko-architecten.nl/ibbn-lent/ (accessed on 17 June 2021).

33. Dostoglu, A.D. Study of Quinta Monroy Housing Project around the Issue of Property. 2011. Available online: https: / / contemporaryagainstme.wordpress.com/2011/09/10/study-of-quinta-monroy-housing-project-around-the-issue-ofproperty / (accessed on 13 December 2017).

34. Archdaily Quinta Monroy/Elemental. Archdaily. 2008. Available online: http://www.archdaily.com/10775/quinta-monroyelemental/ (accessed on 13 December 2017).

35. Galle, W.; Paduart, A.; De Temmerman, N. Evaluation of Temporary Pavilions: LLEXX and Skilpod, a Qualitative Assessment of Adaptability and Generality Related to a Circular Economy; Openbare Vlaamse Afvalstoffen Maatschappij: Mechelen, Belgium, 2016.

36. Timmermans, F. Skilpod: Modulair Wonen Met Circulair Potentieel. 2015. Available online: https://skilpod.com/blog/skilpodmodulair-wonen-met-circulair-potentieel/ (accessed on 17 June 2021).

37. Varinsky, D. This Tokyo Micro Apartment Tower Looks like a Stack of Washing Machines. 2016. Available online: https://www. businessinsider.com/the-nakagin-capsule-tower-in-tokyo-looks-like-a-stack-of-washing-machines-2016-6?r=US\&IR=T (accessed on 17 June 2021).

38. Soares, A.; Magalhaes, F. A Year in the Metabolist Future of 1972. 2014. Available online: https://failedarchitecture.com/2014/0 6/a-year-in-the-metabolist-future-of-1972/ (accessed on 11 January 2021).

39. Archdaily Sharifi-Ha House. Archdaily 2014. Available online: https://www.archdaily.com/522344/sharifi-ha-house-nextoffice (accessed on 11 January 2018).

40. DRMM Architects Sliding House. dRMM. Available online: https://drmm.co.uk/project/sliding-house/ (accessed on 11 January 2018).

41. Aquitanis Projet Pilote Rosa Parks. Available online: http://www.aquitanisphere.com/ (accessed on 11 January 2018).

42. Architizer ME:LU. Architizer 2017. Available online: http://architizer.com/projects/melu/ (accessed on 11 January 2018).

43. Friedman, A. Sustainable dwellings. In Fundamentals of Sustainable Neighbourhoods; Springer International Publishing: Cham, Switzerland, 2015; pp. 143-170. ISBN 978-3-319-10747-9.

44. Bertram, N.; Fuchs, S.; Mischke, J.; Palter, R.; Strube, G.; Woetzel, J. Modular Construction: From Projects to Products; McKinsey \& Company: London, UK, 2019.

45. Gunawerdena, T.; Ngo, T.; Mendis, P.; Aye, L.; Crawford, R.; Alfano, J. A Holistic Model for Designing and Optimising Sustainable Prefabricated Modular Buildings. In Proceedings of the ICSBE2012, University of, Moratuwa, Moratuwa, Sri Lanka, 14-16 December 2012.

46. Nakib, F. Toward an adaptable architecture. Guidelines to integrate adaptability in the building. In Proceedings of the Building a Better World, CIB, Salford Quays, UK, 6 October 2010; p. 14. 
47. OVAM 24 Ontwerprichtlijnen Veranderingsgericht Bouwen 2016. Available online: https://www.ovam.be/ontwikkelingintegratie-evaluatiekader (accessed on 17 June 2021).

48. Vlaamse Maatschappij voor Sociaal Wonen (VMSW) Gezinsleden. Available online: https://www.vmsw.be/Home/Footer/ Over-sociale-huisvesting/Statistieken/Huurders (accessed on 25 February 2017).

49. Debacker, W.; Allacker, K.; De Troyer, F.; Janssen, A.; Delem, L.; Peeters, K.; De Nocker, L.; Spirinckx, C.; Van Dessel, J. Milieugerelateerde Materiaalprestatie van Gebouwelementen; OVAM: Mechelen, Belgium, 2012; p. 361.

50. Buyle, M.; Galle, W.; Debacker, W.; Audenaert, A. Sustainability assessment of circular building alternatives: Consequential LCA and LCC for internal wall assemblies as a case study in a Belgian context. J. Clean. Prod. 2019, 218, 141-156. [CrossRef]

51. Milasi, S.; Gonzalez-Vazquez, I.; Fernandez Macias, E. Telework in the EU before and after the COVID-19: Where We Were, Where We Head To; Science for policy briefs; European Commission, Joint Research Centre: Brussels, Belgium, 2020; p. 8.

52. Peters, R.; Van Den Driessche, C.; Bauwens, D. Hoeveel Kost de Hervorming van Kinderbijslag? VRT NWS. 2014. Available online: https:/ / www.vrt.be/vrtnws/nl/2014/03/24/hoeveel_kost_de_hervormingvandekinderbijslag-1-1916643/ (accessed on 28 May 2021).

53. Ruimte Vlaanderen Opsplitsen of Zorgwonen (Kangoeroewonen). Ruimte Vlaanderen Departement Omgeving. 2017. Available online: https: / / www.omgevingsloketvlaanderen.be/opsplitsen (accessed on 28 May 2021).

54. De Zilveren Sleutel Kangoeroewonen, Een Woonconcept Voor Nu En Later, Voor Jong En Oud. 2014. Available online: https: / /inter.vlaanderen/sites/default/files/Kangoeroewonen_brochure_2014.pdf (accessed on 15 March 2021).

55. Gerards, S.; De Ridder, R.; De Bleeckere, S. Designing multigenerational dwelling: A workshop with four flemish architecture firms. Int. J. Adv. Res. 2015, 9, 20-30. [CrossRef]

56. Vlaamse overheid Gemeenschappelijk Wonen En Woningdelen. Bouwen, Wonen en Energie. 2017. Available online: https: //www.vlaanderen.be/gemeenschappelijk-wonen-en-woningdelen (accessed on 15 March 2021).

57. Larsen, H.G. Three phases of Danish cohousing: Tenure and the development of an alternative housing form. Hous. Stud. 2019, 34, 1349-1371. [CrossRef]

58. Redactie Livios Cohousing: Samen Maar Toch Apart. Livios. Available online: https://www.livios.be/nl/bouwinformatie/ woonwijzer/hoe-wil-ik-wonen/alternatieve-woonvormen/cohousing-samen-maar-toch-apart/ (accessed on 17 June 2021).

59. Sargisson, L. Second-wave cohousing: A modern utopia? Utop. Stud. 2012, 23, 28-56. [CrossRef]

60. De Standaard. Leve de Achterkant. 2007. Available online: https:/ /www.standaard.be/cnt/g891imdt5 (accessed on 28 May 2021).

61. Vermeire, S.; Vanmeirhaeghe, T.; Taillieu, J. Ontwerpend Onderzoek Naar Het Herdenken van de Rijwoning. Master's Thesis, Universiteit Gent, Ghent, Belgium, 2013.

62. Silva, A.; de Brito, J.; Gaspar, J.P. Service life and durability of assemblies. In Methodologies for Service Life Prediction in Buildings; Springer International Publishing: Cham, Switzerland, 2016; p. 432. ISBN 978-3-319-33288-8.

63. BCIS. Life Expectancy of Building Components: A Practical Guide to Surveyors' Experiences of Buildings in Use, 2nd ed.; Connelly-Manton Ltd: London, UK, 2006; ISBN 1-904829-39-2.

64. Galle, W.; De Temmerman, N.; De Meyer, R. Integrating scenarios into life cycle assessment: Understanding the value and financial feasibility of a demountable building. Buildings 2017, 7, 64. [CrossRef]

65. Aspen Aspen Index. Construction Prices for Residential Buildings-New Construction Projects; ASPEN Architecten \& Ingenieurs: Antwerp, Belgium, 2014.

66. Bouwunie. Calculatienormen En Richtprijzen Voor de Woningbouw; 2014-2015 ed.; Bouwunie: Vilvoorde, Belgium, 2014.

67. Wouterszoon Jansen, B.; van Stijn, A.; Gruis, V.; van Bortel, G. A circular economy life cycle costing code (CE-LCC) for building components. Resour. Conserv. Recycl. 2020, 161, 104857. [CrossRef]

68. Invidiata, A.; Ghisi, E. Life-cycle energy and cost analyses of window shading used to improve the thermal performance of houses. J. Clean. Prod. 2016, 133, 1371-1383. [CrossRef] 